\title{
Land Use/Land Cover Changes in the Tlemcen Region (Algeria) and Classification of Fragile Areas
}

\author{
Abdelkader Bardadi ${ }^{1,2}$, Zahira Souidi ${ }^{3, *}\left[\mathbb{D}\right.$, Marianne Cohen ${ }^{4}\left(\mathbb{C}\right.$ and Mohamed Amara ${ }^{1,5}$ \\ 1 Department of Natural and Life Sciences, Belhadj Bouchaib University, Ain Témouchent 46000, Algeria; \\ aekenv@gmail.com (A.B.); amara.univ@gmail.com (M.A.) \\ 2 Department of Ecology and Environment, Abou Bekr Belkaïd University, Tlemcen 13000, Algeria \\ 3 Laboratory LRSBG, Faculty SNV, University of Mascara, Mascara 29000, Algeria \\ 4 Laboratory Médiations, Sorbonne University, 75006 Paris, France; marianne.cohen@sorbonne-universite.fr \\ 5 Laboratory of Ecology and Management of Natural Ecosystems, Abou Bakr Belkaid University, \\ Tlemcen 13000, Algeria \\ * Correspondence: souidi.z@univ-mascara.dz
}

Citation: Bardadi, A.; Souidi, Z.;

Cohen, M.; Amara, M. Land Use/Land Cover Changes in the Tlemcen Region (Algeria) and Classification of Fragile Areas. Sustainability 2021, 13, 7761. https:// doi.org/10.3390/su13147761

Academic Editor: Bernard Lacaze

Received: 25 April 2021

Accepted: 8 July 2021

Published: 12 July 2021

Publisher's Note: MDPI stays neutral with regard to jurisdictional claims in published maps and institutional affiliations.

Copyright: (c) 2021 by the authors. Licensee MDPI, Basel, Switzerland. This article is an open access article distributed under the terms and conditions of the Creative Commons Attribution (CC BY) license (https:/ / creativecommons.org/licenses/by/ $4.0 /)$.

\begin{abstract}
The Tlemcen region is characterized by very diverse and steep areas exposed to gravity hazards, especially in high and medium mountain areas. Tlemcen National Park was chosen for this study, the main objective of which is to map fragile areas in close relation to reduced vegetation cover due to land-use changes and forest fires. Multi-source data were used to monitor land use/land cover (LULC)patterns in the study area between 1987 and 2017. The methodology is based on an object-oriented classification of the Landsat images, using the $\mathrm{K}$ nearest neighbor method for mapping the major LULC classes at the national park level. The results show that LULC is constantly changing in the study area. In 1987, the landscape was made up of (16.5\%) oak forests (holm oak, cork oak, zean oak) and Aleppo pine, which then deteriorated following repeated fires in the nineties to barely represent $7.22 \%$ of the surface in 1995 , followed by a fast forest reclamation, with the forest area doubling in 10 years (13.46\% of the area in 2005), and a near stabilization of the forest cover in 2017 with $14.68 \%$ of the area. These mutations are mainly due to fluctuations in anthropogenic action. Despite past declines and disturbances, the current forested area in the Tlemcen area represents significant forest capital classified as a national park to be protected and developed.
\end{abstract}

Keywords: land use/land cover change; multi-source data; Landsat image; anthropogenic activities; Tlemcen National Park

\section{Introduction}

Mediterranean forests are characterized by a remarkable set of features that make them naturally and aesthetically attractive on the one hand, but also very fragile on the other, requiring careful strategies for their conservation and management. An exceptionally wide variation in environmental conditions characterizes Mediterranean countries, where the environment can limit forest growth and succession but can also give rise to dense forest ecosystems more often than one might think. In addition, Mediterranean forests contain a high level of plant and animal biodiversity, illustrated by a large number of tree species compared to northern forests, and by their relatively high genetic variability due to the survival of many coniferous and deciduous species in the refuges of southern Europe during the ice ages [1]. Humans have interacted with Mediterranean ecosystems for thousands of years, creating a dynamic relationship with their natural environment. It is not possible to understand the current plant structures of the Mediterranean basin without taking into account anthropogenic activities and past land use and land cover (hereafter LULC). Accidental and man-made forest fires, for example, have been an integral part of the life cycle of Mediterranean ecosystems for thousands of years and will remain so in the future. The elimination of all fires is neither environmentally desirable nor physically possible [2]. 
This pressure has created an environment marked by high human activity [3-8]. However, some authors highlighted the resilience of woody species in Mediterranean forests [4,9-11] facing both climatic constraints and disturbances of various origins (fires, grazing, etc.). The new functions of the forest are now increasingly complex, requiring prioritization among sometimes conflicting management objectives. The protected Mediterranean forests are an example of these potential conflicts of use. Regulatory measures to reduce anthropogenic disturbance in forest areas have accelerated the transformation of landscapes into mosaics of plant formations with high biomass and high vertical and horizontal continuity [12,13], increasing their sensitivity to fire. At the same time, urbanization, a global process, also concerns Mediterranean forest areas, regarding the attraction of tourists more particularly, but not exclusively, in the northern Mediterranean region [14]. The land is an important natural resource for the survival and prosperity of the population and the protection of terrestrial ecosystems including the Mediterranean mountains. It is generally considered equivalent to the soil and topography, but this is not correct. According to [15], earth has a broader meaning, including not only the surface and its underlying surface sediments, but also climate, water, plants, animals, and human activities. This means that the earth is a complex entity driven by interacting physical, biological, environmental, social, and economic factors [16].

Anthropogenic pressures generate changes in LULC, the intensity of which depends on the local climate, the type of farming system, the effectiveness of conservation and management policies, and their implementation. These changes can lead to disturbances in natural landscapes and trigger vegetation dynamics, with a direct impact on land-use patterns and biodiversity [17]. Over a long time, for example, during the Classic Greece period (4th to 5th centuries BC), people exploited the environment and used or abused its natural resources such as forests and game species [18]. However, [18] claims that the Mediterranean landscape has changed surprisingly little since ancient times, except for the coasts, deltas, and marshes. By contrast, [18] argues that the changes that destroyed the environment and left behind skeletal landscapes in most mountains are relatively recent, dating back to more than 200 years, and were greater than the slower and more modest changes of previous periods.

Land use in Algeria is still largely dependent on rainfall. Analyzing the relationship between rainfall and land use allows us to understand the concept of choice of speculations adapted to the fluctuations of rainfall. Throughout Algeria, the land remains undercontrolled for a variety of reasons, the most important of which is undoubtedly the lack of an identification that allows for its classification. It is the basis for the establishment of a development policy. Land use is mainly driven by tradition and rainfall, which justifies a large-scale cereal farming practice that providing insurance for the production of the green and dry biomass needed to feed herds. The present situation is also the result of a succession of structuring and restructuring imposed more by theoretical and political visions than by physical, climatic, human, and socio-economic data. The lack of knowledge of the factors in the environment of each space and the lack of capitalizing on the experiences and studies made, have not allowed the establishment of a clear and sustained rule of management. The absence of an institution to coordinate the planning and operation of the spaces according to well-defined rules has resulted in a succession of attempts, the failure of which is constant [19].

The degradation of vegetation formations in Algeria has been addressed by several authors [20-28]. This degradation is defined by [29] under the terms of matorralization, dematorralization, and therophytization. More generally, many authors [30-35] define ecosystem degradation as an inability to retain, use and recycle local resources, like water, energy, and nutrients.Indeed, the natural environment represents a functional unit independent of the energy flow and the cycle of matter between its various components in continuous interaction [36].

Slopes are transformed into places of ecological transition and discontinuity which, if not contained, initiate chain processes of destruction [37]. Undoubtedly, land-use dy- 
namics have direct consequences on the availability of natural resources [38]. Work carried out on vegetation formations in the Tlemcen region also shows the degradation of their floral processions [39-41], with interpenetration between forest and non-forest processions linked to a strong heterogeneity of forest areas. The decline in forest cover in the southern Mediterranean has also led to severe soil erosion. Other authors have, however, qualified this diagnosis [4] or even noted a recent stabilization of forest areas in the southern Mediterranean since the 1990s, particularly in Algeria [42].

In this context, long-term monitoring of LULC and new balances should be sought in the Mediterranean so that their environment and the prosperity of the mountain people should be preserved [16].

The study of LULC changes is an essential contribution to the assessment of humanenvironment interactions. Thus, LULC information is useful to identify appropriate strategies for better land management. Several methods have been developed and applied for this purpose, with different levels of effectiveness $[43,44]$, including remote sensing data processing for the classification of different LULC classes, and GIS [14]. The present study aims to analyze LULC changes, over 30 years (from 1987 to 2017) in Tlemcen National Park (here after TNP). To date, no study has objectively addressed a multi-date analysis of LULC changes in TNP based on the object-oriented classification method.

\section{Study Area}

TNP is located in northwest Algeria (Figure 1). It is one of the most recent national parks in Algeria and was created on 12 May 1993 by decree n93/117 for the conservation of the fauna and flora evolving in a sub-humid climate, of the pine forest resulting from 110 years-old reforestation, and of natural sites. TNP is located entirely in the wilaya of Tlemcen (Figure 1). It extends over the territory of seven communes with a surface area of 8225.04 ha. However, an extension is under study which would bring its surface area to 9000 ha.

In the Tlemcen Mountains, several works have dealt with climate characterization and bioclimate classification. These works were carried out in Algeria, the Tafna catchment area, and the Tlemcen Mountains in general, and the region under consideration in particular. It will be a question of making a bibliographical synthesis. In 1999, research on the regionalization of annual total precipitation in north-western Algeria was carried out by Medjerab and Henia (2005). A period of 48 years (1942-1990) recorded in 220 meteorological stations shows that the TNP area receives average annual total precipitation exceeding $500 \mathrm{~mm}$. The climatic data of the Hafir station for the period from 1975 to 1991 shows that the average annual total precipitation for this station is $674 \mathrm{~mm}$ /year, the maximum average annual temperature is $18.9^{\circ} \mathrm{C}$, the minimum average annual temperature is $8.2^{\circ} \mathrm{C}$, the average annual temperature is $13.6^{\circ} \mathrm{C}$ [45]. According to [46], the climate of the area is close to the Mediterranean type, like the northwestern part of Algeria, characterized by:

- The concentration of rainfall during the cold period (autumn and winter)

- An apparent drought during the hottest months (summer)

- The length of the dry season is on average four months, covering the summer season.

The research, undertaken on the climate of the area by the National Agency for Hydraulic Resources, the National Office of Meteorology, and the TNP, has shown that its bioclimate is sub-humid (in Ourit, Hafir, and Meffrouch stations) with a few stations with an upper semi-arid climate [47-49]. Other works, often associated with floristic studies, show a regionalization of bioclimates. For example, the sub-humid type has been confirmed in 2009 by [42] in the Hafir station, by using the EMBERGER quotient $(Q 2=82.70)$. In the northern part of the Tlemcen mountains where the Zarifet forest is located, the climate is semi-arid superior according to the study conducted by [46]. The use of EMBERGER's rainfall quotient and DeMARTONNE's aridity index allows the area studied to be classified in the sub-humid bioclimatic stage with cool winters, with some semi-arid stations in temperate winters. Finally, in the Aïn Fezza Mountains [50], located in the eastern part of the TNP, the bioclimate is defined as semi-arid with a temperate winter, except at higher 
altitudes where it is subhumid with a temperate winter, with an EMBERGER's rainfall quotient equal to 65.51 and the average minimum temperature of $5.2^{\circ} \mathrm{C}$. The semi-arid and cool bioclimate appears above $400 \mathrm{~m}$ above sea level and extends to the steppe domain.

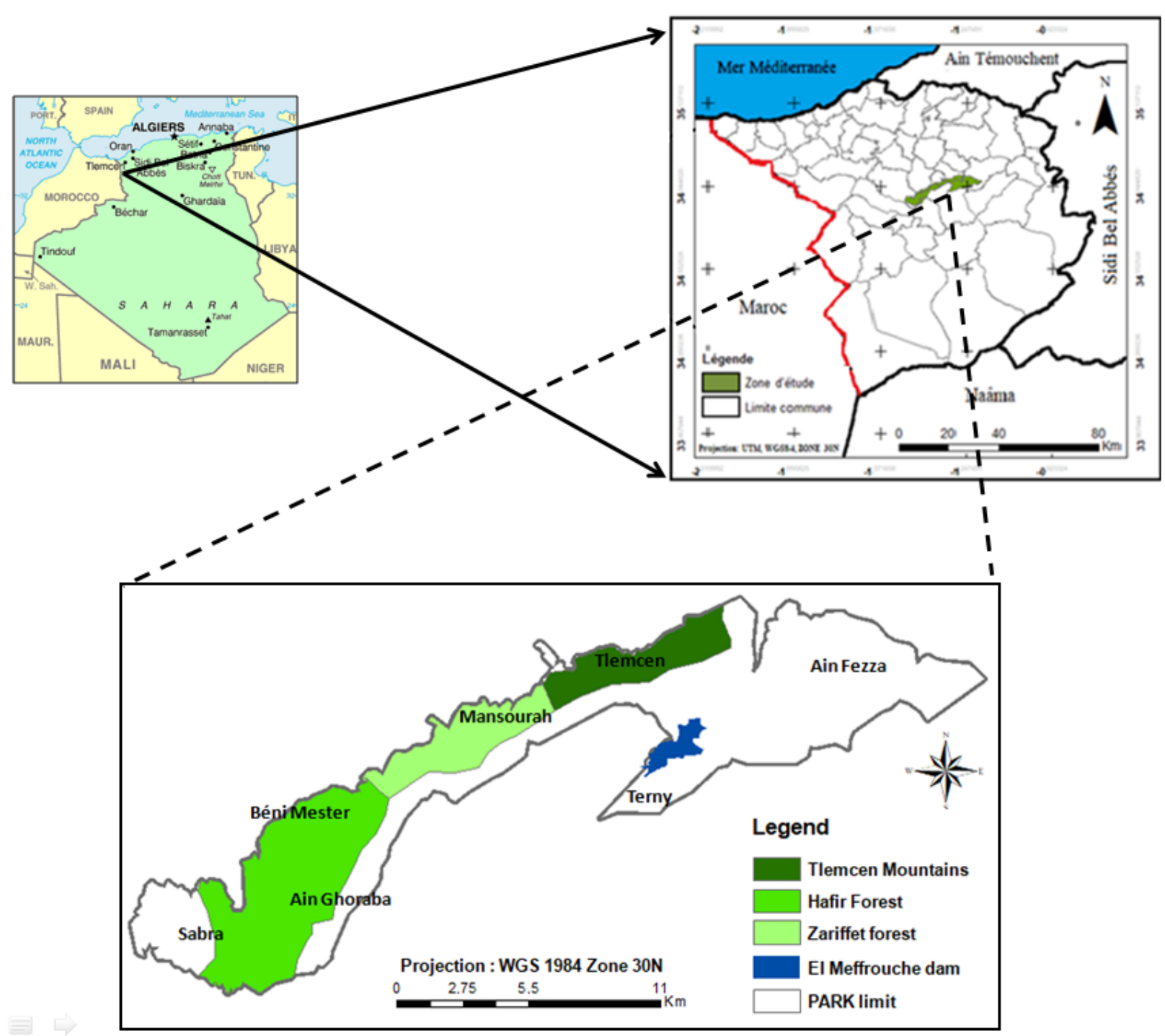

Figure 1. Location map of the TNP.

The territory of the park is underlain by a series of sedimentary layers whose historical evolution originates from the Jurassic to the Quaternary benches and shows two large litho-stratigraphic distinct series that are described from the bottom up: Ancient series (Upper Jurassic-Lower Cretaceous) and recent series (Lower Miocene-Quaternary). The park's topography is very diverse. It is composed mainly of the forested mountain chain on Jurassic lands, and the plains and valleys located on Tertiary and Quaternary lands. The mountain chain contains several Djebels with Djebel El Koudia being the highest with an altitude of $1418 \mathrm{~m}$. The altitude in Hafir varies from $700 \mathrm{~m}$ in the canton of Tebount to $1418 \mathrm{~m}$ at the top of the canton of Jebel Koudiat Hafir, while in Zarifet, it is between 1000 and $1200 \mathrm{~m}$. Three classes of slopes (3-12.5\%, 12.5-25\%, and 25-50\%) attest to rugged terrain, especially in the mountains, while the valleys and plateaus have a slight slope of $0-3 \%$. These flat fields are much localized (Plateau de Lalla Setti-Ain Fezza-El Meffrouche). According to the pedological sketch [39-51], the dominant soil types are calcareous brown soils alternating with travertines, red fersiallitic soils, and dolomites, terra-fusca type fersiallitic brown soils, some of which are of a green character. 
The park offers considerable potential for the development of tourism, particularly for eco-tourism. In terms of flora, the park hosts 953 species, 39 of which are protected and mainly present in forests. Among these forests, there is the Tlemcen forest, located upstream of the city, which was planted in 1890 to protect the city. It is a leisure forest of 286 ha, at an average altitude of 1096 meters. This old forest consists of a pure stand of Aleppo pine (Pinus halepensis).Its undergrowth consists of cade juniper (Juniperus oxycedrus), thorny broom (Calicotome spinosa), holm oak (Quercus ilex), and asphodel (Asphodelus sp.). There are also the state forests of Hafir (1653 ha), located at the western edge of the park and made up of cork oak (Quercus suber) and holm oak, of Zarifet (931 ha), dominated by cork oak and zean oak (Quercus canariensis), the waterfalls and the cliffs of El-Ourit, and finally, of Moutas, mainly made up of zean oak. Other species notably hawthorn (Crataegus monogyna), shiny geranium (Geranium lucidum), gumrockrose (Cistus ladaniferus), Cytisus triflorus, kermes oak (Quercus coccifera), Astragalus sp., mastic tree (Pistacia lentiscus), terebinth (Pistacia terebinthus), dwarf palm (Chamaerops humilis), laurustinus (Viburnum tinus) and strawberry tree (Arbutus unedo), provide freshness and beauty to the area and are an asset for ecotourism and nature tourism. In addition, these natural sites have become observation points for the interpretation of plant natural species and environmental education besides being just recreational and leisure spaces, such as the Lalla Setti plateau, El Ourit waterfalls.

The forests of the park are the State's property managed by the forest law (Law 84-12 of 23 June 1984). The agricultural lands which are considered as a working void are either deprived of individual property or leases of the services of the forests.

The National Park is a natural area of national interest, established to protect the integrity of one or more ecosystems. Its objective is to ensure the conservation and protection of unique natural regions, due to their biological diversity, while making them accessible to the public for research and educational purposes. The aim is both to protect and enhance the cultural and historical heritage, both material and intangible, while promoting environmentally friendly leisure and relaxation activities, with a view to sustainable tourism. Thus, TNP is considered a tool for the conservation and development of the Tlemcen area.

Sustainable economic development, in general, and sustainable tourism, in particular, are at the heart of the project, but the involvement and participation of the local population in the decision-making process and the development of tourism are practically non-existent.

\section{Material and Methods}

\subsection{Material}

To analyze the spatio-temporal evolution of LULC in TNP, four series of Landsat satellite images taken in late spring were used (Table 1). These images have the advantage of covering the entire study area with sufficient spatial resolution to map the spatiotemporal evolution of forest landscapes.

Table 1. Landsat satellite images used.

\begin{tabular}{cccc}
\hline Date of Acquisition & Satellite & Sensor & Spatial Resolution \\
\hline $18-05-1987$ & Landsat 5 & TM & $30 \mathrm{~m}$ \\
$06-04-1995$ & Landsat5 & TM & $30 \mathrm{~m}$ \\
$19-05-2005$ & Landsat7 & ETM+ & $30 \mathrm{~m}$ \\
$18-04-2017$ & Landsat7 & ETM+ & $30 \mathrm{~m}$ \\
\hline
\end{tabular}

\subsection{Image Pre-Processing}

This phase is essential for superimposing and simultaneously exploiting images taken by different sensors and at different dates [52,53]. The pre-processing stage aims to simplify segmentation by reinforcing the resemblance between pixels belonging to the same region, or by increasing the dissimilarity between pixels belonging to different regions [54].

Radiometric calibration: if digital remote sensing images are used in their raw form, gross errors can propagate in all subsequent image processing operations. The purpose of calibration is to correct certain anomalies due to the sensors and to convert the received 
signal into a physical value: radiance. It is then necessary to calibrate the satellite data if an efficient representation of the Earth's surface is to be obtained [55].

The extraction of the study area is based on a geometrical type of cutting using a vector provided by the management of TNP.

The technique of object-oriented classification with the eCognition software was used to have an overview of the geography of the LULC classes.

Many authors [56-59] have sought to compare "object" and "pixel" classification methods. The "object" method offers a major advantage in that it is much faster than the "pixel" technique. Accuracy is greater due to the technical possibilities offered by Definiens eCogniton ${ }^{\circledR}$ in improving and correcting the sampling during the classification process, so the interpreted land cover categories are more complicated for pixel classification via ENVI 5.3 or Erdas Imagine 9.1.

The tools manipulated for this study are:

- ENVI 5.3 image processing software for geometric image corrections and color compositions;

- eCognition software for image classification: this works somewhat differently than most software that classifies images. Instead of working at the pixel level, i.e., using pixels as fundamental classification objects, eCognition first generates its own objects, called "image objects", by using a parametrizable segmentation process. Then these objects are classified using one of the techniques available in the software, for example, range of spectral values, shape, neighborhood;

- The GIS software, ArcGIS 10.5 for digitizing and creating land use maps and change maps.

\subsection{Fieldwork and Validation of the Classifications Obtained}

In addition to the verification and validation of the thematic classes defined before the image classification stage, the fieldwork consisted of recording GPS points for each of these classes. These points were used to validate the mapping results for the most recent year. They are completed by a visual interpretation of Google Earth images (2005 and 2017), Google Earth Engine, and Sentinel 2 acquired in 2017. Similarly, we have drawn on other sources of additional information to validate our results on land-use maps produced by $[40,60]$.

\section{LULC Change Mapping}

To assess the changes in LULC, several statistical indicators have been calculated; these are the rates of change and the transition matrix.

- Calculation of rates of change (global rate of change and annual rate of change): according to the equation proposed by [61] (1) and [62]) (2) frequently used to measure growth between two given periods [63-65]. The rates of change in the area of LULC classes between the years 1987 and 2017 were calculated as follows:

$$
\begin{gathered}
T g=(S 2-S 1) \times 100 / S 1 \\
T c=(\ln S 2-\ln S 1) \times 100 /(t 2-t 1) \times \ln \mathrm{e}
\end{gathered}
$$

With:

- $\quad S 1$ the area of a unit area class at date $\mathrm{t} 1$;

- $\quad S 2$ is the area of the same area unit class at date t2.

In the Naperian logarithm; e the base of the Naperian logarithms (e = 2.71828).

Positive values represent an increase in the surface area of the class during the period under study, where as negative values show the loss of surface area between the two dates. For values close to zero, they express the relative stability of the class.

- Transition matrix: The transition matrix provides the opportunity to highlight LULC changes over a given period $[66,67]$. The values in the columns represent the proportions of areas occupied by each land-use class at a time (j) and those in the rows at the initial time (i). The cells of the matrix contain the value of a variable that has changed 
from an initial class (i) to a final class (j) during the period under consideration. It is acquired by crossing the LULC maps of 1987, 1995, 2005, and 2017 and made feasible by the "Intersect polygons" algorithm of the Geoprocessing extension under ArcGIS 10.5. The modifications are of three categories: (i) progressions which correspond to the increase in area of a class (positive change), (ii) regressions which correspond to the change from one class to another in terms of a decrease in its initial area (negative change), (iii) and stability which corresponds to the absence of change in the thematic class during the study period.

- Typology of changes: Based on the transition matrix, the observed changes were classified according to the process types: stability, mutation (from one type of forest to another, or from farm to urban areas), degradation (decrease of the vegetal cover), degradation by fire, development (cultivation or urbanization of former natural areas), reclamation (densification of the vegetal cover). Each of these processes was then detailed at the starting date of the period where the percentage of the area was calculated for each type.

\section{Results}

\subsection{Validation of Classifications and Mapping Results}

The digitization of topographic maps and the interpretation of Landsat images have made it possible to produce LULC maps for the years 1987, 1995, 2005, and 2017 (Figure 2).Overall, the values of the different precision indicators of the object-oriented classification, obtained for the different images, reflect on the one hand, the good quality of the samples and, on the other hand, the good correspondence between the result of the classification and the spatial reality contained in the images.

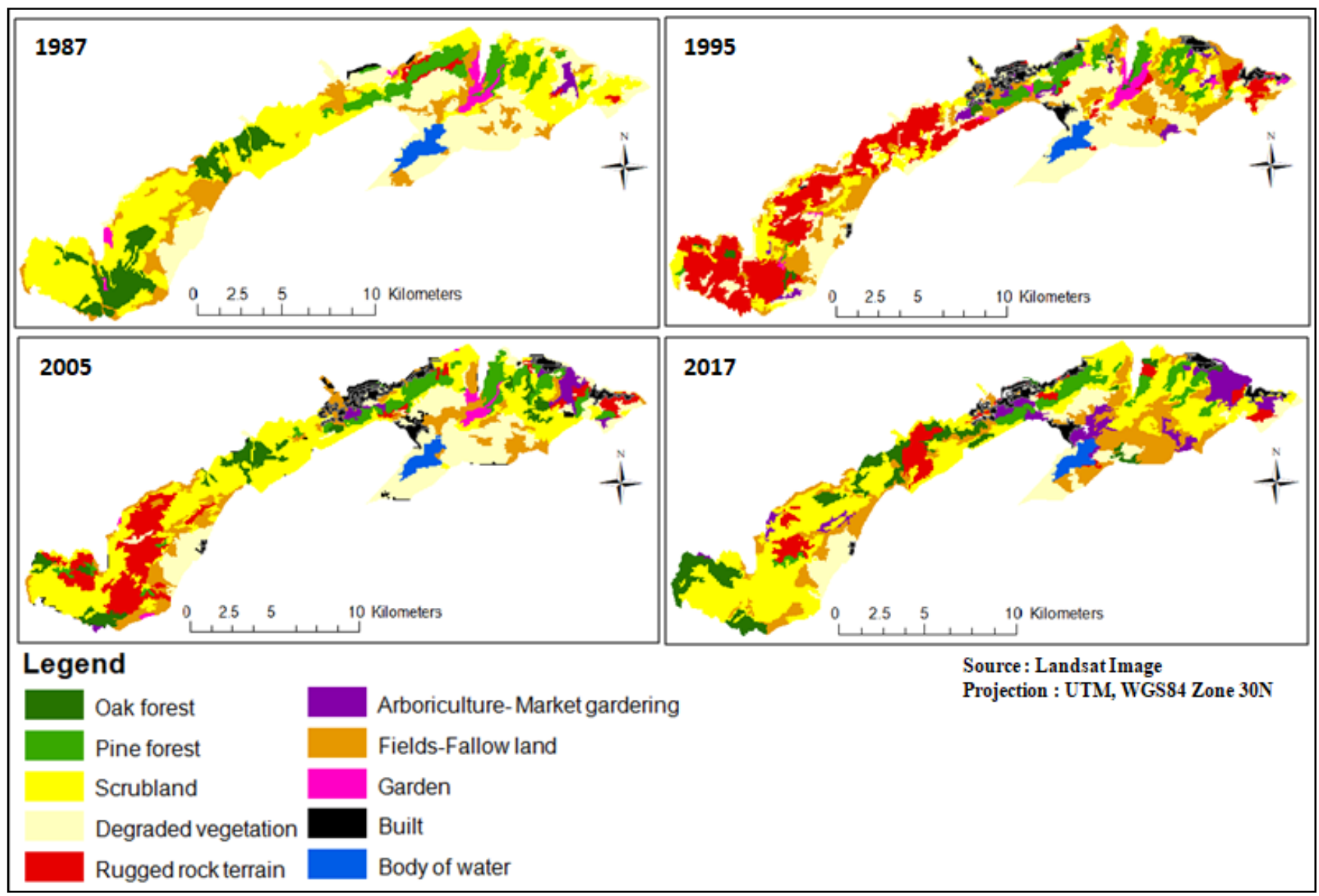

Figure 2. Land Use Land Cover classes of maps in TNP for the years1987, 1995, 2005, and 2017. 


\subsection{Analysis of the Changes of LULC}

The evaluation analysis of the changes of LULC makes it possible to highlight the changes that have taken place between the different periods: 1987-1995, 1995-2005, 2005-2017, and 1987-2017. Thus, the average annual rate of spatial expansion, the transition matrix, and the rate of change have been calculated based on the areas of these units.

\subsubsection{Areas and Average Spatial Expansion Rate}

Table 2 summarizes the different LULC classes, their surface area, and their average annual rate of spatial expansion during the periods 1987-1995, 1995-2005, and 2005-2017.

Table 2. Land-use changes in TNP from 1987 to 2017.

\begin{tabular}{|c|c|c|c|c|c|c|c|c|c|c|c|c|c|c|c|c|}
\hline \multirow{3}{*}{$\begin{array}{l}\text { LULC } \\
\text { Class }\end{array}$} & \multicolumn{8}{|c|}{ Area in $\mathrm{Ha}$ and \% } & \multicolumn{8}{|c|}{ Change Rate in \% } \\
\hline & \multicolumn{2}{|c|}{1987} & \multicolumn{2}{|c|}{1995} & \multicolumn{2}{|c|}{2005} & \multicolumn{2}{|c|}{2017} & \multicolumn{2}{|c|}{$87-95$} & \multicolumn{2}{|c|}{ 95-05 } & \multicolumn{2}{|c|}{ 05-17 } & \multicolumn{2}{|c|}{$87-17$} \\
\hline & $\mathrm{Ha}$ & $\%$ & $\mathrm{Ha}$ & $\%$ & $\mathrm{Ha}$ & $\%$ & $\mathrm{Ha}$ & $\%$ & $\mathrm{Tg}$ & Tc & $\mathrm{Tg}$ & Tc & $\mathrm{Tg}$ & Tc & $\mathrm{Tg}$ & Tc \\
\hline CO-ZOF & 754.4 & 9 & 61.2 & 0.73 & 453.3 & 5.44 & 751.3 & 9.01 & -91.88 & -31.3 & 640.7 & 19.96 & 65.73 & 4.19 & -0.405 & -0.01 \\
\hline AP F & 625.2 & 7.5 & 541.4 & 6.49 & 668.9 & 8.02 & 472.9 & 5.67 & -13.41 & -1.79 & 23.55 & 2.10 & -29.29 & -2.87 & -24.35 & -0.92 \\
\hline CL-CV S & 3299 & 40 & 1182 & 14.2 & 2639 & 31.7 & 3058 & 36.6 & -64.16 & -12.78 & 123.2 & 8.00 & 15.87 & 1.22 & -7.305 & -0.25 \\
\hline DV & 2137.7 & 26 & 2524 & 30.3 & 1772. & 21.3 & 827.6 & 9.9 & 18.07 & 2.07 & -29.77 & -3.52 & -53.30 & -6.32 & -61.28 & -3.15 \\
\hline B-R-L & 78.84 & 0.9 & 1940 & 23.3 & 1049 & 12.6 & 521.7 & 6.3 & 2360.9 & 39.9 & -45.89 & -6.12 & -50.29 & -5.80 & 561.7 & 6.27 \\
\hline $\mathrm{F}-\mathrm{F}$ & 1016.5 & 12 & 1478 & 17.7 & 1080 & 13 & 1456 & 17.4 & 45.42 & 4.66 & -26.88 & -3.12 & 34.72 & 2.47 & 43.24 & 1.19 \\
\hline A-MG & 58.5 & 0.7 & 188.5 & 2.26 & 210.8 & 2.53 & 620.4 & 7.44 & 222.15 & 14.57 & 11.84 & 1.11 & 194.32 & 8.96 & 960.4 & 7.84 \\
\hline Gar & 165.9 & 2 & 197.5 & 2.37 & 102.7 & 1.23 & 142.5 & 1.70 & 19.03 & 2.17 & -48.01 & -6.52 & 38.73 & 2.72 & -14.15 & -0.50 \\
\hline Bui & 26.9 & 0.3 & 90.09 & 1.08 & 270.9 & 3.25 & 355.2 & 4.26 & 234.78 & 15.05 & 200.7 & 10.97 & 31.09 & 2.24 & 1219 & 8.57 \\
\hline WB & 174.24 & 2.1 & 133.7 & 1.6 & 88.6 & 1.06 & 131.7 & 1.56 & -23.24 & -3.29 & -33.78 & -4.10 & 48.67 & 3.29 & -24.43 & -0.93 \\
\hline Total & 8337 & 100 & 8337 & 100 & 8337 & 100 & 8337 & 100 & & & & & & & & \\
\hline
\end{tabular}

CO-ZO F: Cork oak and zean oak forests; APF: Aleppo pine forests; CL-CV S: Cork oak and holm oak scrubland; DV: Degraded vegetation; B-R-L: Burnt rocky land; F-F: Fallow fields; A-MG: Arboriculture-Market gardening; Gar: Garden; Bui: Building; WB: Water body; Tg: Global rate of change; Tc: Annual rate of change.

\subsubsection{The Period 1987-1995}

The positive values of the rates reveal an increase in surface areas, between 1987 and 1995 , of the occupation classes such as arboriculture-market gardening $(222.15 \%)$, building $(234.78 \%)$, fields and fallow land $(45.42 \%)$, and the very important appearance of rocky land following forest fires $(2360.96 \%)$. The negative values indicate that during the same period, the areas of LULC classes such as oak forest, pine woods, and scrubland decreased by $91.58 \%, 13.41 \%$, and $64.16 \%$, respectively, at a rate of $31.30 \%, 1.79 \%$, and $12.78 \%$ per year.

\subsubsection{The Period 1995-2005}

For the period 1995-2005, the table shows an annual increase of $19.96 \%, 2.10 \%, 8.00 \%$, $10.97 \%$, and $1.11 \%$ respectively for the area covered by oak forest, pine forest, scrubland, buildings, and arboriculture-market gardening, while there is an average annual decrease of $3.12 \%, 3.52 \%$, and $6.12 \%$ of the surface areas of fallow fields, degraded vegetation, and rocky land resulting from fires. This leads to an increase in the surface areas of oak forest, pine woods, scrubland, arboriculture-market gardening as well as built areas, which increase respectively from $0.73 \%$ to $5.44 \%$, from $6.49 \%$ to $8.02 \%$, from $14.2 \%$ to $31.7 \%$, from $2.26 \%$ to $2.53 \%$, and from $1.08 \%$ to $3.25 \%$. During the same period, the areas covered by fallow fields, degraded vegetation, and burnt rocky land decreased from $17.7 \%$ to $13 \%$, $30.3 \%$ to $21.3 \%$, and $23.3 \%$ to $12.6 \%$ respectively.

\subsubsection{The Period 2005-2017}

The oak forest, which occupied $5.44 \%$ in 2005 , increased to $9.01 \%$ in 2017 , an increase of $65.73 \%$. The same is true for the units of scrubland, fallow fields, arboriculture-market gardening, and built area, which have increased respectively from $31.7 \%$ to $36.6 \%$, from $13 \%$ to $17.4 \%$, and from $3.25 \%$ to $4.26 \%$, with an annual rate of progression estimated respectively at $1.22 \%, 2.47 \%, 8.96 \%$, and $2.24 \%$. This increase corresponds to a decrease in Aleppo pine forest areas, burnt rocky land, and the class of degraded vegetation with an annual rate of regression of $2.87 \%, 6.32 \%$, and $5.80 \%$ respectively. 


\subsection{Transition Matrix}

Transition matrices reveal the changes in LULC classes in TNP between 1987-1995, 1995-2005, 2005-2017, and 1987-2017 (Table 3). From these transition matrices, some change processes are identified, and the percentages of affected areas calculated (Table 4).

Table 3. Transition matrices in hectares (ha), derived from the overlay of LULC change from 1987 to 2017.

\begin{tabular}{|c|c|c|c|c|c|c|c|c|c|c|c|}
\hline (a) & \multicolumn{11}{|c|}{1995} \\
\hline 1987 & CO-ZOF & AP F & CL-CVS & DV & B-R-L & F-F & A-MG & Gar & Bui & WB & Total \\
\hline $\mathrm{CO}-\mathrm{ZO} F$ & 26.37 & 7.74 & 70.47 & 33.39 & 576.54 & 34.65 & 0.63 & 4.59 & 0 & 0 & 754.38 \\
\hline AP F & 14.58 & 382.32 & 63.54 & 24.66 & 38.25 & 42.3 & 28.35 & 27.36 & 3.87 & 0 & 625.23 \\
\hline CL-CV S & 12.24 & 98.82 & 736.38 & 552.78 & 1219.68 & 560.07 & 67.59 & 45 & 6.39 & 0 & 3298.95 \\
\hline DV & 0 & 8.73 & 85.77 & 1557.81 & 53.46 & 322.29 & 69.48 & 1.71 & 36.9 & 1.35 & 2137.5 \\
\hline B-R-L & 0 & 40.68 & 12.6 & 5.4 & 9 & 4.5 & 3.06 & 2.52 & 1.08 & 0 & 78.84 \\
\hline F-F & 1.17 & 2.7 & 155.7 & 295.92 & 29.97 & 485.82 & 17.19 & 10.71 & 17.28 & 0 & 1016.46 \\
\hline A-MG & 0 & 0.27 & 30.6 & 0 & 0.09 & 15.39 & 2.16 & 9.99 & 0 & 0 & 58.5 \\
\hline Gar & 6.84 & 0.09 & 27.27 & 15.21 & 7.74 & 13.14 & 0 & 95.67 & 0 & 0 & 165.96 \\
\hline Bui & 0 & 0 & 0 & 1.17 & 2.43 & 0 & 0 & 0 & 23.31 & 0 & 26.91 \\
\hline WB & 0 & 0 & 0 & 37.71 & 2.88 & 0 & 0 & 0 & 1.26 & 132.39 & 174.24 \\
\hline Total & 61.2 & 541.35 & 1182.33 & 2524.05 & 1940.04 & 1478.16 & 188.46 & 197.55 & 90.09 & 133.74 & 8337 \\
\hline (b) & \multicolumn{11}{|c|}{2005} \\
\hline 1995 & CO-ZOF & AP F & CL-CV & DV & B-R-L & F-F & A-MG & Gar & Bui & WB & Total \\
\hline $\mathrm{CO}-\mathrm{ZO} F$ & 18.9 & 18.72 & 3.51 & & 12.87 & 7.11 & 0 & 0.09 & 0 & 0 & 61.2 \\
\hline $\mathrm{APF}$ & 26.46 & 377.01 & 100.89 & 6.21 & 23.94 & 1.53 & 4.77 & 0 & 0.54 & 0 & 541.35 \\
\hline CL-CV S & 101.25 & 101.43 & 590.04 & 58.32 & 141.93 & 143.1 & 38.61 & 2.07 & 5.49 & 0.09 & 1182.33 \\
\hline DV & 14.67 & 13.59 & 549.36 & 1339.56 & 34.2 & 336.42 & 21.96 & 28.62 & 184.23 & 1.35 & 2523.96 \\
\hline B-R-L & 250.47 & 96.48 & 806.22 & 63.45 & 680.58 & 16.02 & 18.45 & 0.81 & 7.56 & 0 & 1940.04 \\
\hline F-F & 40.41 & 19.8 & 510.12 & 226.89 & 103.05 & 474.39 & 82.17 & 3.69 & 15.3 & 2.34 & 1478.16 \\
\hline A-MG & 0.18 & 12.33 & 48.06 & 16.92 & 24.75 & 48.6 & 31.14 & 0 & 6.48 & 0 & 188.46 \\
\hline Gar & 0 & 29.52 & 23.04 & 0.45 & 28.08 & 37.17 & 11.88 & 67.41 & 0 & 0 & 197.55 \\
\hline Bui & 0.99 & 0 & 7.56 & 14.58 & 0.27 & 13.59 & 1.8 & 0 & 51.3 & 0 & 90.09 \\
\hline WB & 0 & 0 & 0.09 & 46.08 & 0 & 2.79 & 0 & 0 & 0 & 84.78 & 133.74 \\
\hline Total & 453.33 & 668.88 & 2638.89 & 1772.46 & 1049.67 & 1080.72 & 210.78 & 102.69 & 270.9 & 88.56 & 8337 \\
\hline (c) & \multicolumn{11}{|c|}{2017} \\
\hline 2005 & CO-ZOF & AP F & CL-CV & DV & B-R-L & F-F & A-MG & Gar & Bui & WB & Total \\
\hline $\mathrm{CO}-\mathrm{ZO} \mathrm{F}$ & 214.92 & 14.85 & 145.17 & 0 & 61.83 & 16.56 & 0 & 0 & 0 & 0 & 453.33 \\
\hline $\mathrm{APF}$ & 69.03 & 329.22 & 143.73 & 1.17 & 83.16 & 3.06 & 12.51 & 23.85 & 3.15 & 0 & 668.88 \\
\hline CL-CV S & 295.47 & 57.24 & 1716.57 & 14.49 & 181.53 & 304.2 & 56.52 & 5.4 & 7.38 & 0.27 & 2639.07 \\
\hline DV & 39.51 & 1.26 & 165.24 & 718.38 & 28.44 & 532.26 & 156.06 & 1.44 & 83.52 & 46.35 & 1772.46 \\
\hline B-R-L & 80.37 & 50.22 & 697.05 & 8.28 & 129.06 & 6.75 & 76.05 & 0 & 1.89 & 0 & 1049.67 \\
\hline F-F & 34.74 & 10.44 & 157.41 & 42.84 & 19.89 & 560.79 & 151.02 & 43.47 & 57.78 & 2.34 & 1080.72 \\
\hline A-MG & 8.82 & 9 & 5.22 & 8.37 & 11.97 & 3.78 & 147.06 & 0 & 16.56 & 0 & 210.78 \\
\hline Gar & 0 & 0 & 15.48 & 0 & 0 & 16.02 & 3.15 & 68.04 & 0 & 0 & 102.69 \\
\hline Bui & 8.19 & 0.72 & 12.24 & 34.11 & 5.85 & 12.6 & 12.15 & 0.27 & 184.68 & 0 & 270.81 \\
\hline WB & 0 & 0 & 0 & 0 & 0 & 0 & 5.85 & 0 & 0 & 82.71 & 88.56 \\
\hline Total & 751.05 & 472.95 & 3058.11 & 827.64 & 521.73 & 1456.02 & 620.37 & 142.47 & 354.96 & 131.67 & 8337 \\
\hline
\end{tabular}

CO-ZO F: Cork oak forests, zean oak forests; AP F: Aleppo pine forests; CL-CV S: Cork oak and holm oak scrubland; DV: Degraded vegetation; B-R-L: Burnt rocky land; F-F: Fallow fields; A-MG: Arboriculture-Market gardening; Gar: Garden; Bui: Building; WB: Water body; Tg: Global rate of change; Tc: Annual rate of change.

\subsubsection{From 1987 to 1995: Destruction of Scrubland and Forests by Large Fires}

Between 1987 and 1995, several negative dynamics accumulated and affected almost half of the surface area of Tlemcen Park (47\%): fires, anthropogenic pressure, and the degradation of woody formations (Figure 3). The areas that have remained stable represent $41 \%$ of the surface area, while fires have destroyed nearly a quarter $(23 \%)$, with scrublands being twice as affected by fires as forests ( $14 \%$ and $7 \%$ of the surface area, respectively). In addition to this destruction by fire, there has been a degradation of woody formations (nearly $9 \%$ ), in particular scrublands (6\% of the surface area), as well as a development of natural surfaces $(15 \%)$, which have been transformed into agricultural or urban surfaces. The plant reclamation represents only $10 \%$ of the surface area (Table 4 ). 
Table 4. Percentage of surface areas affected by types of change ( $\mathrm{DV}^{*}$ : degraded vegetation).

\begin{tabular}{|c|c|c|c|c|c|c|c|}
\hline \multirow[t]{2}{*}{ Process } & \multirow{2}{*}{ Type of Change } & \multicolumn{2}{|c|}{ 1987-1995 (in \%) } & \multicolumn{2}{|c|}{ 1995-2005 (in \%) } & \multicolumn{2}{|c|}{ 2005-2017 (in \%) } \\
\hline & & Detail & Process & Detail & Process & Detail & Process \\
\hline Stability & Stability & 41.40 & 41.40 & 44.56 & 44.56 & 49.80 & 49.80 \\
\hline \multirow[t]{2}{*}{ Mutation } & Type of Forest & 0.27 & \multirow{2}{*}{1.29} & 0.54 & \multirow{2}{*}{3.25} & 1.01 & \multirow{2}{*}{4.90} \\
\hline & Farmed versus urban areas & 1.02 & & 2.71 & & 3.90 & \\
\hline \multirow[t]{2}{*}{ Degradation } & Forest degradation & 2.30 & \multirow[b]{2}{*}{8.93} & 1.33 & \multirow[b]{2}{*}{2.03} & 3.48 & \multirow[b]{2}{*}{3.65} \\
\hline & Scrubland degradation & 6.63 & & 0.70 & & 0.17 & \\
\hline \multirow[t]{4}{*}{ Wildfire } & Forest altered by fire & 7.37 & \multirow{4}{*}{23.16} & 0.44 & \multirow{4}{*}{4.43} & 1.74 & \multirow{4}{*}{4.71} \\
\hline & Scrubland altered by fire & 14.63 & & 1.70 & & 2.18 & \\
\hline & $\mathrm{DV}^{*}$ altered by fire & 0.64 & & 0.41 & & 0.34 & \\
\hline & Fire on man-made areas & 0.52 & & 1.87 & & 0.45 & \\
\hline \multirow[t]{4}{*}{ Development } & Development of the forest & 1.70 & \multirow{4}{*}{15.16} & 0.17 & \multirow{4}{*}{9.82} & 0.71 & \multirow{4}{*}{16.04} \\
\hline & Developmentof the scrubland & 8.15 & & 2.27 & & 4.48 & \\
\hline & Development of $\mathrm{DV}^{*}$ & 5.18 & & 6.87 & & 9.83 & \\
\hline & Development of burnt areas & 0.13 & & 0.51 & & 1.02 & \\
\hline \multirow{5}{*}{ Reclamation } & From scrubland to forest & 1.33 & \multirow{5}{*}{10.06} & 2.43 & \multirow{5}{*}{35.91} & 4.23 & \multirow{5}{*}{20.90} \\
\hline & From $\mathrm{DV}^{*}$ to scrubland & 1.13 & & 6.59 & & 1.98 & \\
\hline & From $\mathrm{DV}^{*}$ to forest & 0.00 & & 0.34 & & 0.49 & \\
\hline & Farmabandonment & 6.89 & & 11.96 & & 4.17 & \\
\hline & Post-fire recovery & 0.70 & & 14.59 & & 10.03 & \\
\hline
\end{tabular}

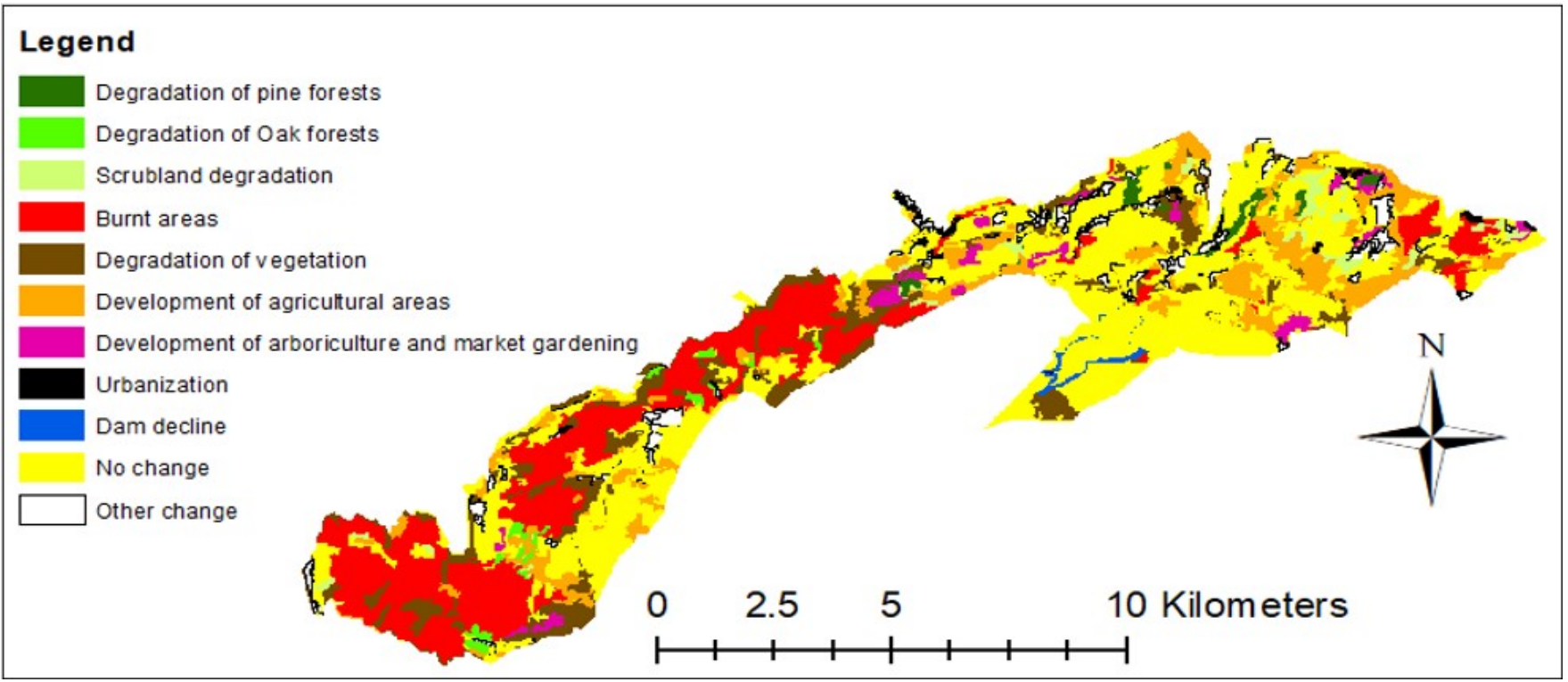

Figure 3. Spatial distribution of landscape changes between 1987 and 1995.

According to Table $3 a, 728.01$ ha of the 754.38 ha of the study area occupied by the cork oak and zean oak forest were converted into other LULC classes, while only 26.37 ha remained unchanged. The burnt rocky terrain, degraded vegetation, and fallow fields are the main beneficiaries of this conversion with respectively 576.54 ha, $70.47 \mathrm{ha}, 34.65$ ha, and 33.39 ha of surface area increasing, and totality respectively $1219.68 \mathrm{ha}, 560.07 \mathrm{ha}$, $552.78 \mathrm{ha}$, and $67.59 \mathrm{ha}$. The increase of the surface area of the burnt rocky terrain was mainly observed to the detriment of forest formations (oak and pine forests) and scrubland.

The Aleppo pine forest has experienced a slight regression; the classes benefiting from this regression are respectively the scrubland class, fallow fields, and burnt rocky ground. The same observation is made for the cork oak, and holm oak scrubland 2562.57 ha of the 3298 ha of the study area occupied in 1987 have been transformed into other land use classes against 736.38 ha which has remained unchanged. 
The agricultural areas have seen a significant increase (186.3 ha for arboriculturemarket gardening and 992.34 ha for fallow fields). It should be pointed out that this increase has been to the detriment of the classes of scrubland and degraded vegetation.

Another LULC class that has seen a significant increase is that of the built environment. If more than $88 \%$ ( 23.31 ha) has remained unchanged, we nevertheless note an increase of 66.78 ha.

4.3.2. From 1995 to 2005: Revegetation of Burnt Rocky Land, Abandoned Agricultural Land and Degraded Land

Between 1995 and 2005, the trend was reversed compared to the previous period and there was a fairly spectacular biological recovery, linked to the post-fire revegetation and agricultural decline (Figure 4$)$. Stable areas increase slightly (44.5\%), and above all, there is a significant plant recovery $(35.9 \%)$, in part on the land that has been burnt during the previous period $(14.5 \%)$, another part on abandoned crops (nearly $12 \%$ ), a smaller proportion being due to the densification of degraded areas (6.5\%). At the same time, the trend towards the agricultural or urban development of natural vegetation has been reduced by a third compared to the previous period $(9.8 \%)$, the areas affected by the regression in the density of natural vegetation being four times less $(2 \%)$ and those destroyed by fire more than five times less (4\%) than during the previous period (Table 4).

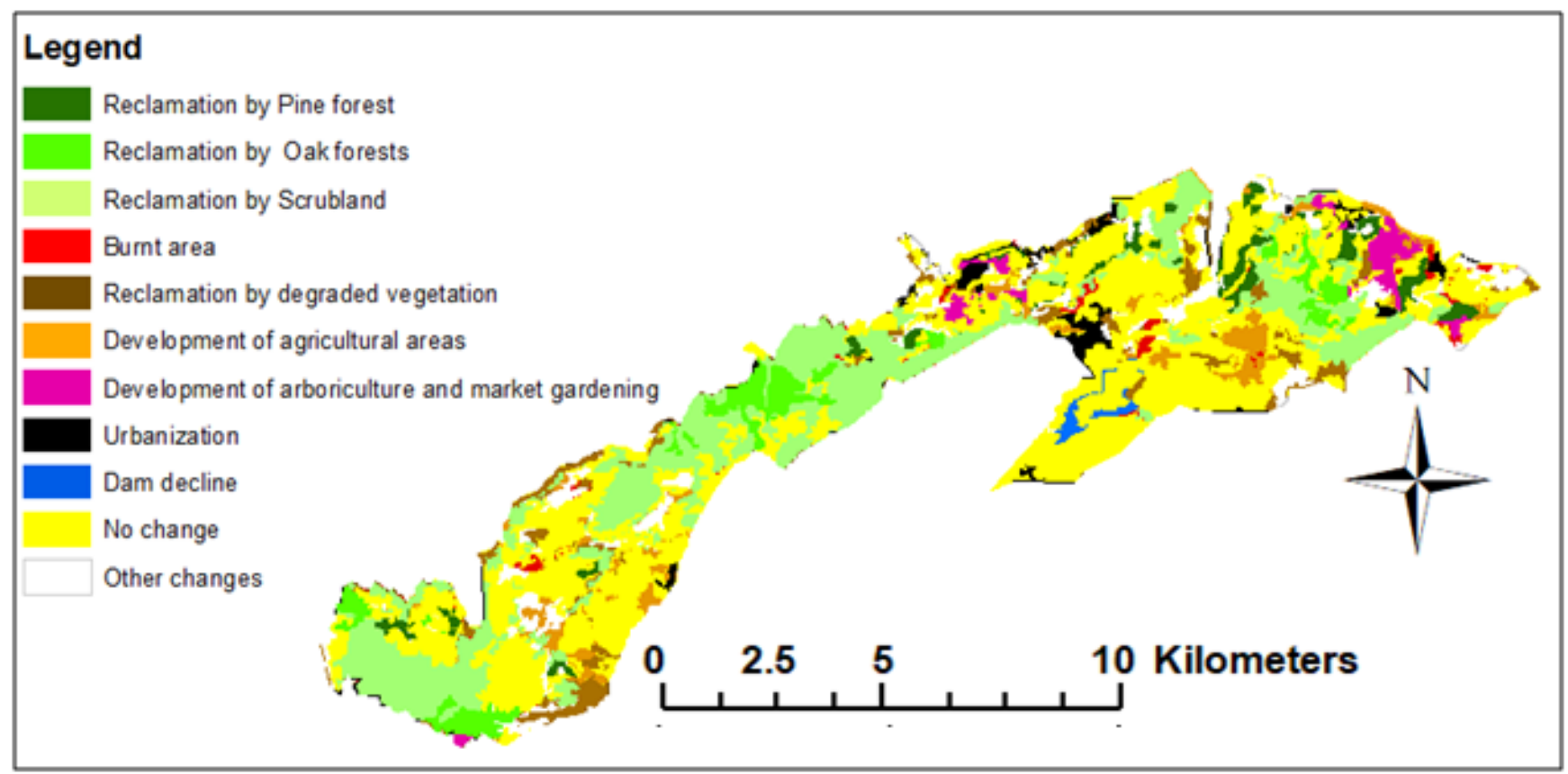

Figure 4. Spatial distribution of landscape changes between 1995 and 2005.

According to Table $3 \mathrm{~b}$, only 18.9 ha of the cork oak and zean oak forest area remained unchanged in 2005. This class increased significantly by $434.43 \mathrm{ha}$. The same observation is made for the two other woody formations (scrubland and Aleppo pine), which increased by 2048.85 ha and 291.87 ha, respectively.

Another LULC class has undergone a significant transformation, the rocky land burnt down. Although more than 680.58 ha of the total surface area remained unchanged, a good part of it was occupied in 2005 by scrubland ( 806 ha), cork oak and zean oak forest (250.47 ha), Aleppo pine forest (96.48 ha), and degraded vegetation (63.45 ha).

As for the agricultural areas, only 474.39 ha of the 1478.16 ha have remained unchanged for the fallow field class, 1003 ha have been abandoned and reclaimed by scrubland (510 ha), or by degraded vegetation (226 ha), another part has been degraded by wildfire (burnt rocky land, 103 ha) and another converted to arboriculture and market gardening (82.17 ha). During the same period, the surface area occupied by arboriculture- 
market gardening thus recorded an increase of 179 ha. This increase was mainly to the detriment of the fallow field class (82.17 ha).

4.3.3. From 2005 to 2017: Stabilization of Natural Vegetation and Extension of Arboriculture

During the period 2005 to 2017, the proportion of stable surfaces represents almost half of the region studied (49.8\%); the trend towards plant reclamation continues, but now only concerns $20.9 \%$ of the surfaces, half of which is linked to the post-fire recovery (Figure 5). A trend towards the development of the natural vegetation is again observed, affecting $16 \%$ of the areas, and mainly concerning degraded vegetation (9.8\%) and scrublands (4.5\%) transformed into orchards or urban areas (Table 4). The trend towards the degradation of natural vegetation is increasing by $3.65 \%$ on surface areas, mainly forest areas, but the degradation is half as much as it was during the period 1987-1995. Destruction by wildfire remains at the same level as during the previous period $(<5 \%$ of the surface areas).

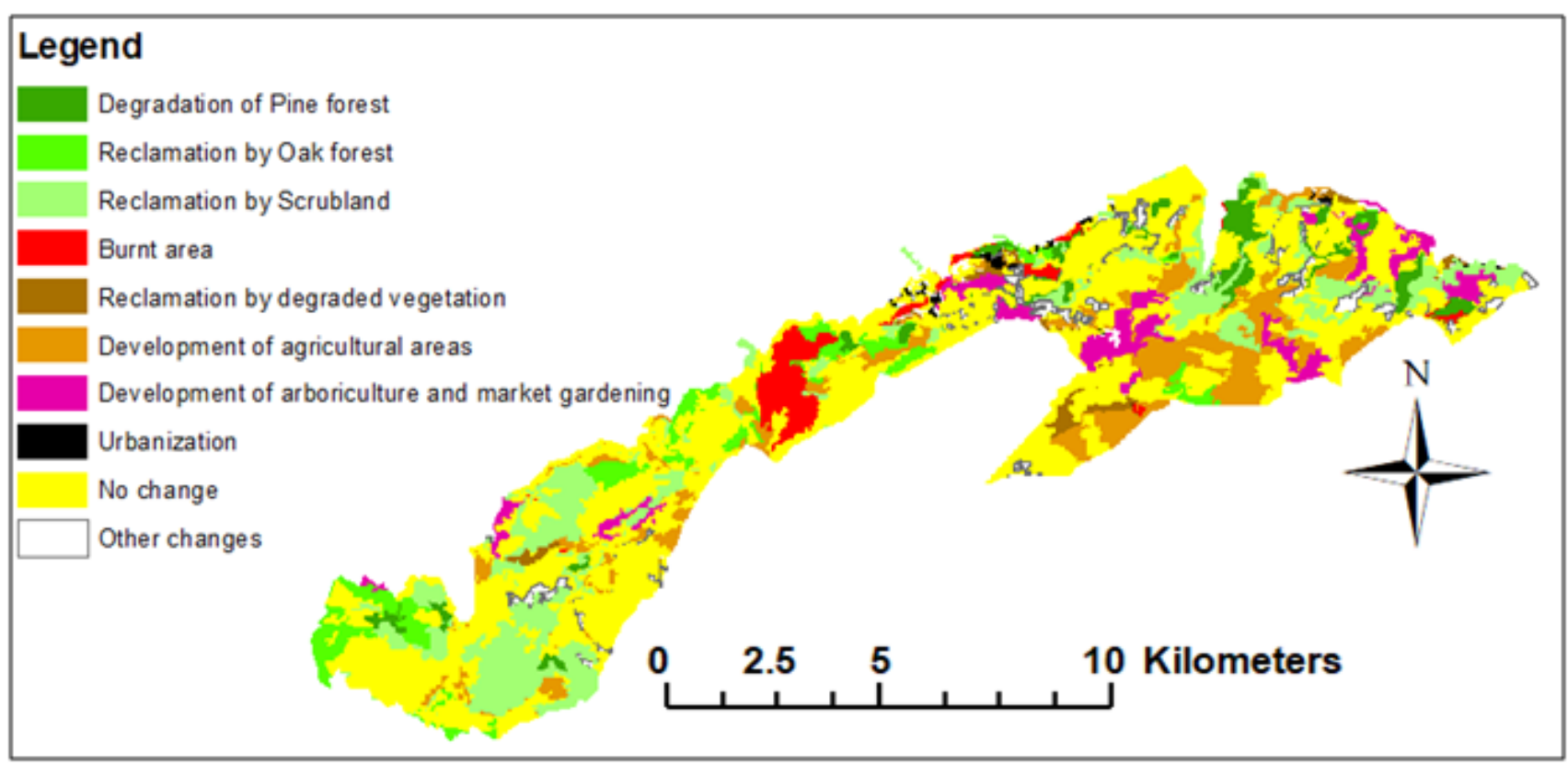

Figure 5. Spatial distribution of landscape changes between 2005 and 2017.

In detail, Table 3c shows a variable progression for the majority of LULC classes. Concerning the cork oak, and zean oak forest, while almost half of its initial surface area, i.e., 214.92 ha out of 453.33 ha, has remained unchanged, a lesser part has been degraded and transformed into scrubland (145.17 ha) and burnt rocky ground (61.83 ha). It should be noted that in parallel with this regression (238 ha), the oak forests experienced an increase twice more as significant (536.13 ha), particularly due to the re-growth of burnt rocky land (80.37 ha) and scrubland (295 ha).

More than 295.47 ha of scrublands have been transformed into cork oak and zean oak forests, 181.53 ha into burnt rocky land, 304 ha into fallow fields, and 56.52 ha into arboriculture-market gardening. However, scrubland has experienced a remarkable progression of 1341.54 ha due to the regaining of vegetation from the burnt rocky terrain (697 ha), degraded vegetation (165 ha), and fallow fields (157 ha), in contrast to the regressive dynamic of the cork oak and zean oak forests (145 ha) and Aleppo pine forests (143 ha).

The fallow fields, arboriculture, and market gardening land uses have retained respectively 560 ha and 147 ha of their surface areas. However, it is worth noting important transitions in the classes of degraded vegetation and cork oak and holm oak scrubland in agricultural areas with 688.32 ha and 360.70 ha, respectively.

The built-up class retains its 184.68 ha and has recorded an increase of 170.28 ha as a result of the conversion of degraded vegetation (83.52 ha), fallow fields (57.78 ha), and 
arboriculture-market gardening (16.56 ha). Urbanization has therefore developed on the agricultural land surrounding the villages.

\section{Discussion}

Between 1987 and 2017, the LULC in TNP widely varied in significance and magnitude, mainly due to human activity, which plays a decisive role, interacting with the topographical factor. During this period and in general, the TNP has undergone four scenarios:

\subsection{The Regression of the Forest Area and the Progression of Rocky Outcrops Following Fires}

The forest of Hafir (located in the south-western part of the National Park) consisted mainly of an old cork oak forest of 200-250 years old, with some coppices of this type from war exploitation; there were only rare traces of natural regeneration [22]. In the past, in addition to aging, this oak forest has suffered all kinds of destruction, particularly due to fires, severe illegal cutting, and overgrazing. As a result, many trees have disappeared irreversibly [68].

At the beginning of the last century, the forest of Zarifet (located in the central part of the national park) was made up of stands of oak trees between 80 and 90 years old, very poor and badly venerated, burnt in 1892 over an area of about 450 hectares [69]. In the 1950s, these trees were already in a fairly advanced state of deterioration due to their very slow growth, high density of united stands, and very high height with a very small diameter [70].

During the period 1987-1995, the regression of vegetation and fires contributed to an increase in natural risks (erosion, landslides, and scree slopes). Old holm oak and cork oak forests have disappeared under the combined action of man and fires, most being of anthropogenic origin.

This mutation was mainly observed in the forests of Hafir and Zarifet. This area is characterized by several classes of slopes (Figure 6). This change is mainly due to the action of repeated fires throughout the Tlemcen region. During the period from 1987 to 2017, the region of Tlemcen experienced considerable variations in burnt areas, with fluctuations from one year to another.

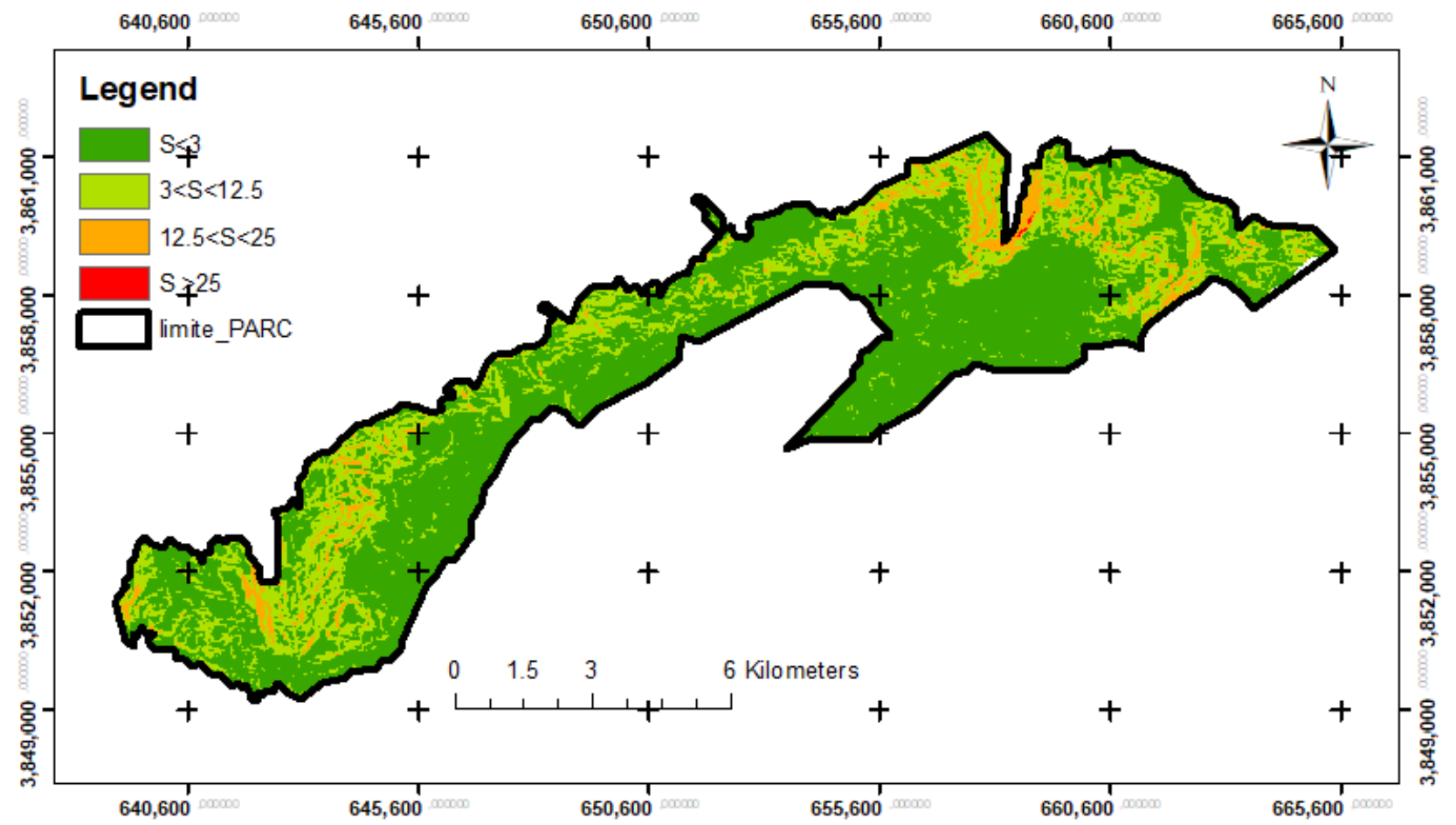

Figure 6. Slope map. 
According to Figure 7, there were several peaks in the number of fires in the Tlemcen region. The year 1994 was the most catastrophic in terms of burnt area and number of fires, due to the unstable conditions the country experienced that year, with more than 640 ha destroyed in the national park. Nevertheless, our image analysis showed a more dramatic picture, with a surface of 1930 ha affected by fire during the period 1987-1995. This result is consistent with previous works that have shown that steep slopes may favor the spreading of the fire [71] and are at the same time a cause of inadequate management [72].

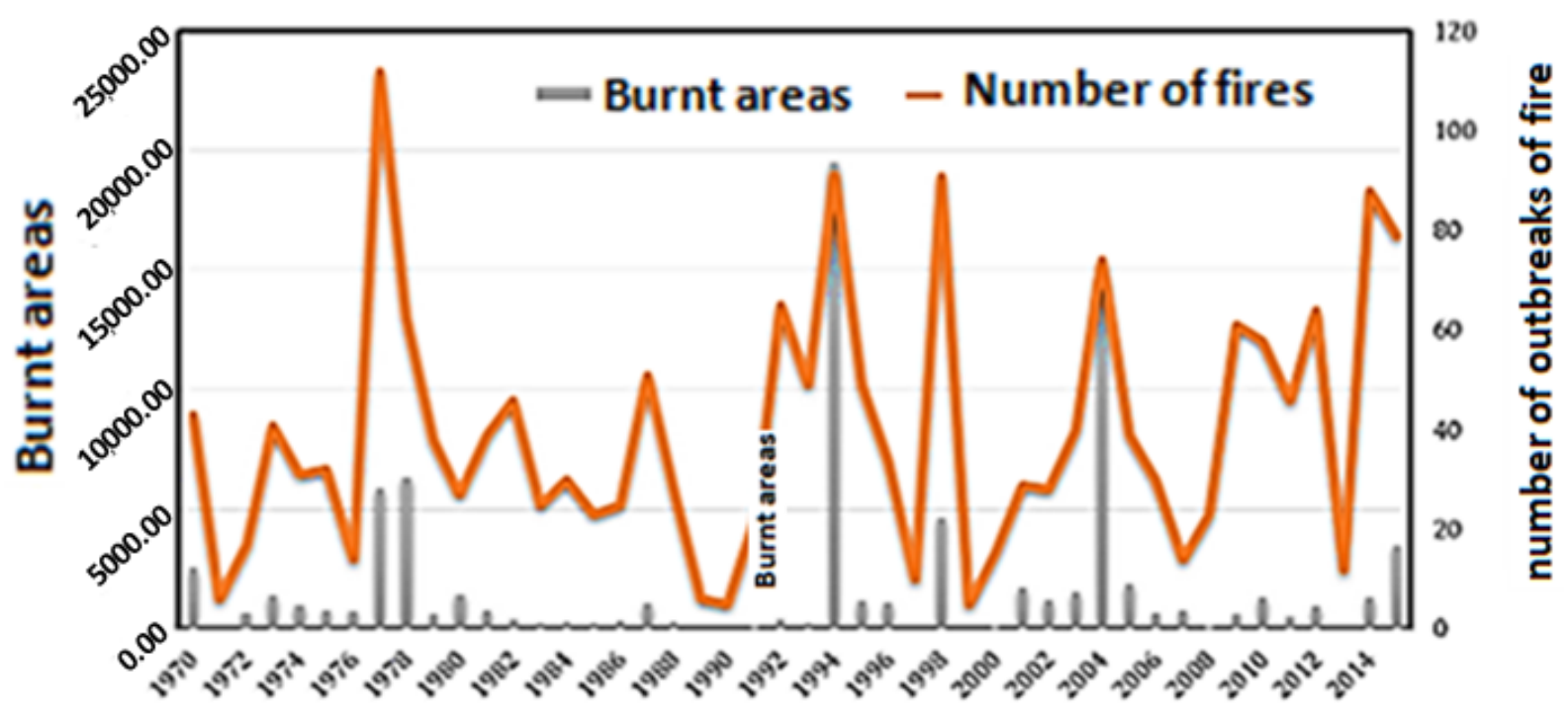

Figure 7. Burnt areas (ha) and number of fires in the wilaya of Tlemcen during the period 1970-2015 [73].

The national park was a victim of several fires during the period (2000-2017) with varying areas (Figure 7).

The areas of rocky outcrops observed in 2005 (Figure 2) are mainly due to a fire that occurred in 2004 with a burnt area of 187 ha in the Hafir forest to the west of the TNP. The rocky outcrops observed in 2017, are the result of burnt areas in the forest of Zarifet especially in 2015. We still observe a significant difference between the surfaces of burnt areas during the periods 1995-2005 and 2005-2017 (369 ha and 392 ha respectively), computed from our analysis and these statistical data.

In fact, there is a yearly fire-fighting campaign that starts in June and ends in September (4 months), but the prolonged drought in western Algeria favors fire that starts from May and continues beyond September. The insufficient means of the forestry services do not allow for a more prolonged fire-fighting campaign that concentrates only on the summer period. The large areas burnt were recorded in July (45\%) and August (43\%). During September and October, the areas burnt are smaller. During this reference period, the number of outbreaks and the largest areas burned is recorded during the months of July and August (Figures 8 and 9).

\subsection{Progression of the Surface Area of Forest}

In most cases, foresters allow nature to regenerate by itself after a fire. "If we don't replant, it's above all because the trees always end up growing back, even if it takes longer", explains Frédéric Prodhomme, a forester in the Vaucluse who saw, in July 2017, a fire that burnt 1200 hectares of pine and oak trees in the Luberon Natural Park (France). However, three to five years are enough to reduce the visual impact on the landscape with the ground covered by herbaceous plants and the first regrowth of shrub and tree species. "We observed that new seeds were deposited naturally on the ground after the fire, because the heat helped open the cones of the pine trees. We're counting on it a lot," continues Frédéric Prodhomme. It will take an average of 70 to 100 years to find trees 10 to 20 meters high. 


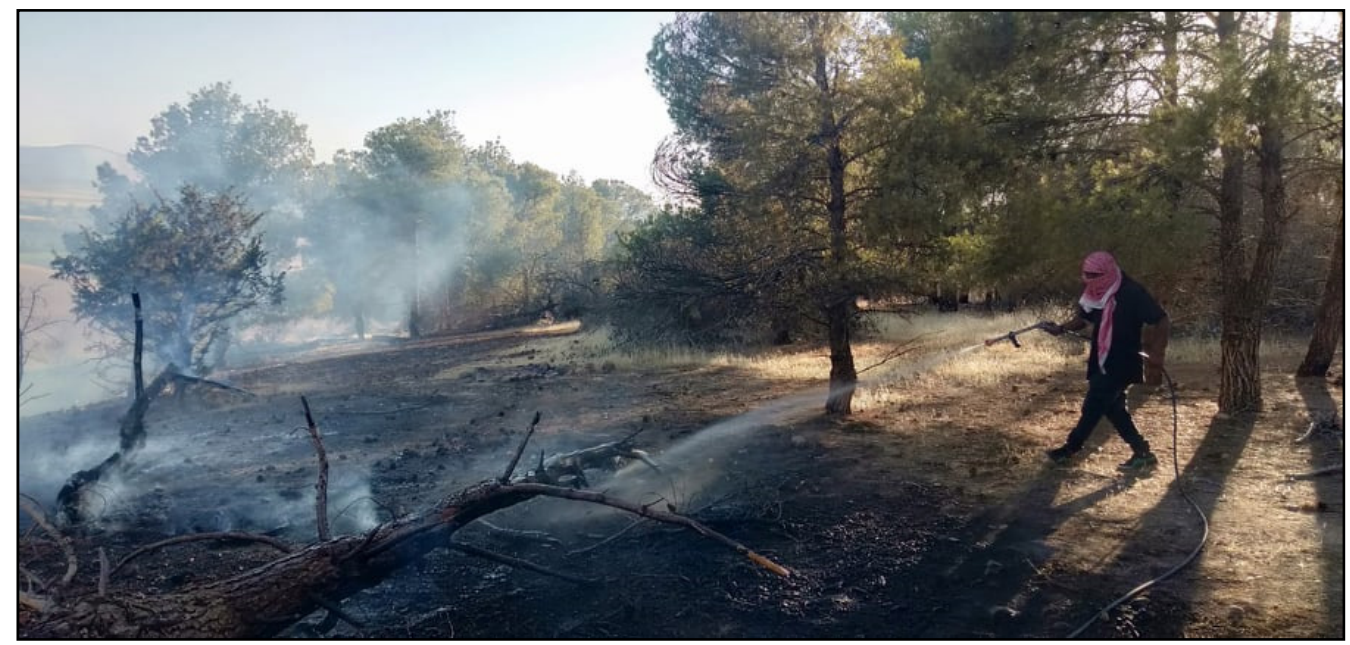

Figure 8. Oak forest fire (Zarifet forest). (Photograph by authors, taken on 30 July 2017).

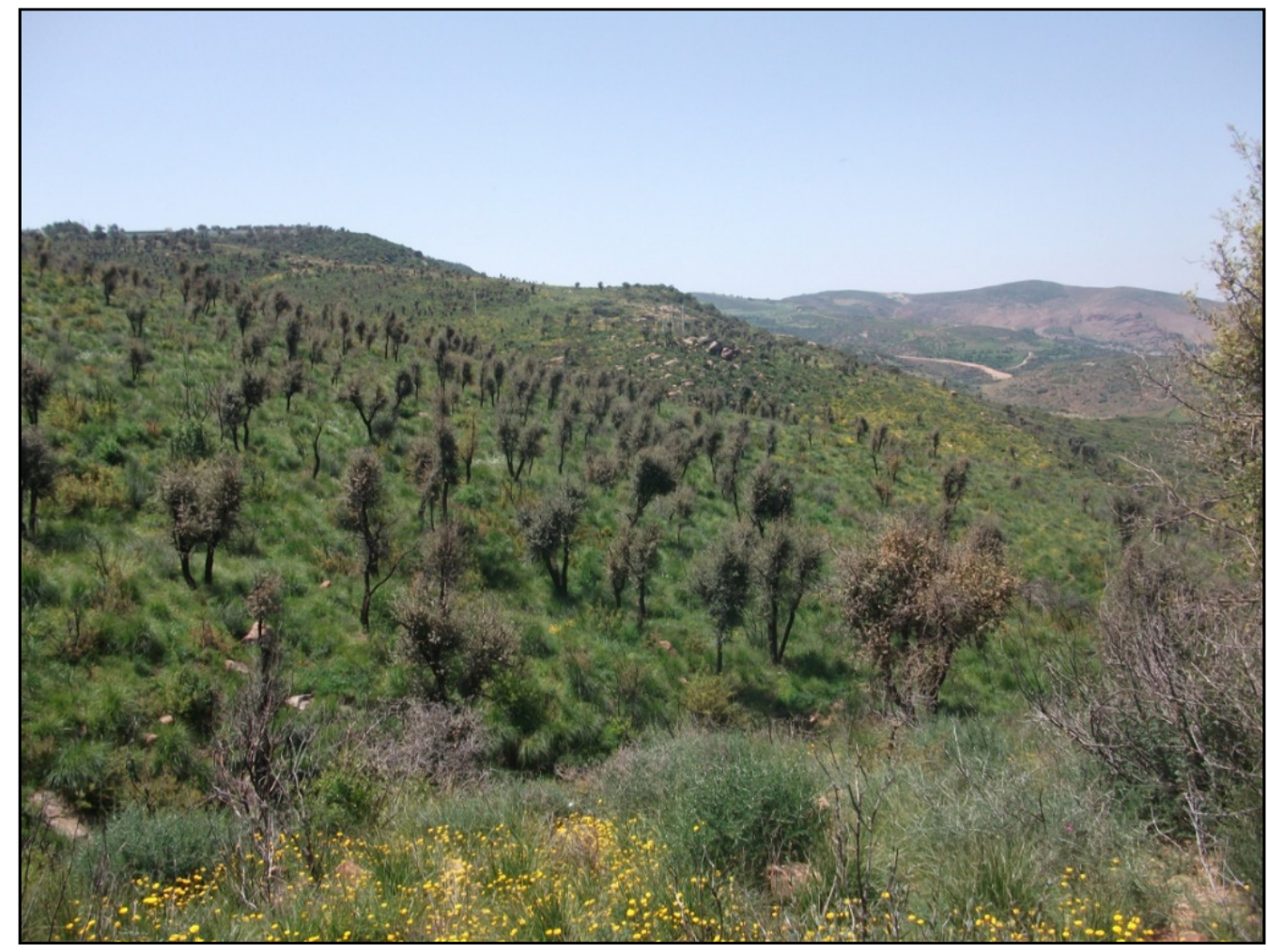

Figure 9. Oak forest affected by fire (Hafir forest). (Photograph by authors, taken on 15 October 2017).

In the TNP, the increase in forest area is mainly due to natural plant reclamation on the one hand and reforestation operations in cork oak, Atlas cedar, Aleppo pine, and gable pine on the other. The plant reclamation is mainly due to the classification of the area as a National Park, which has made it possible to defend burnt areas and reforested areas to promote the recovery of vegetation. Without this classification, it would have been difficult because the forests are public domain and therefore free of access, particularly for abusive grazing and illegal cutting. A financial envelope was dedicated to the TNP for the conservation and enhancement of the site as early as 1993 and stricter regulations were introduced.

Between 2005 and 2013, the region of Tlemcen underwent a very significant reforestation program with a total area of 728 ha, divided between the four state forests of the TNP. The forest of Hafir benefited from a large part of the cork forest reconstitution program 
with 478 hectares, which represents a rate of $66 \%$. In second place is the state forest of Zarifet with an area of 170 ha, with a rate of $23 \%$, followed by the forest of Ifri with an area of 50 ha (7\% of the total). Finally, in the state forest of Zerdeb, plantations covered a relatively small area of around 30 ha, i.e., a rate of $4 \%$. The progress observed by our analysis is therefore largely due to the actions of the foresters.

Table 5 shows that in the TNP, reforestation work has been carried out almost annually during the last decade, with an annual average of about 74 ha. During this period, we record two years of low activity, namely 2006 and 2008. It is in 2005 (the year of the effective start of the cork oak reforestation projects in the region of Tlemcen) that the reforested area is the highest, about 170 ha (or $46 \%$ of the total reforestation program in the park), carried out in the Zarifet forest (4 plots). It is followed by the year 2009, with an area of 153 ha $(41.57 \%)$ recorded in total in the Hafir forest. During the other years (2007 and 2010), the reforested areas vary respectively between 40 and 5 ha.

Table 5. Geographical characteristics of the different reforestation plots in the Tlemcen National Park.

\begin{tabular}{|c|c|c|c|c|c|c|c|}
\hline $\begin{array}{c}\text { Site } \\
\text { Number }\end{array}$ & State Forest & Canton & Location Name & Geographical Coordinates & $\begin{array}{l}\text { Area } \\
\text { (ha) }\end{array}$ & Year & Ownership \\
\hline 01 & Hafir & Oued Tlet & Oued Tlet & $\begin{array}{l}34^{\circ} 47^{\prime} 14^{\prime \prime} \mathrm{N} \\
1^{\circ} 25^{\prime} 52^{\prime \prime} \mathrm{O}\end{array}$ & 150 & 2009 & \multirow{3}{*}{ TNP } \\
\hline 02 & Hafir & Oued Tlet & KoudietHafir & $\begin{array}{c}34^{\circ} 47^{\prime} 00^{\prime \prime} \mathrm{N} \\
1^{\circ} 25^{\prime} 39^{\prime \prime} \mathrm{O}\end{array}$ & 05 & 2010 & \\
\hline 03 & Hafir & Oued Tlet & GharLahmame & $\begin{array}{c}34^{\circ} 46^{\prime} 58^{\prime \prime} \mathrm{N} \\
1^{\circ} 26^{\prime} 29^{\prime \prime} \mathrm{O}\end{array}$ & 03 & 2009 & \\
\hline 04 & Hafir & $\begin{array}{l}\text { Oued } \\
\text { Fernane }\end{array}$ & Oued Fernane 1 & $\begin{array}{c}34^{\circ} 46^{\prime} 55.4^{\prime \prime} \mathrm{N} \\
1^{\circ} 26^{\prime} 26.5^{\prime \prime} \mathrm{O}\end{array}$ & 50 & 2005 & \multirow{6}{*}{$\begin{array}{l}\text { Conservation of } \\
\text { Tlemcen forests }\end{array}$} \\
\hline 05 & Hafir & Kréane & dhaya & $\begin{array}{c}34^{\circ} 48^{\prime} 25.55^{\prime \prime} \mathrm{N} \\
1^{\circ} 28^{\prime} 06.93^{\prime \prime} \mathrm{O}\end{array}$ & 40 & 2007 & \\
\hline 06 & Zarifet & Zarifet & Zarifet 1 & $\begin{array}{l}34^{\circ} 50^{\prime} 9.0^{\prime \prime} \mathrm{N} \\
1^{\circ} 21^{\prime} 32.7^{\prime \prime} \mathrm{O}\end{array}$ & 40 & 2005 & \\
\hline 07 & Zarifet & Zarifet & Zarifet 1 & $\begin{array}{c}34^{\circ} 50^{\prime} 49.8^{\prime \prime} \mathrm{N} \\
1^{\circ} 21^{\prime} 5.4^{\prime \prime} \mathrm{O}\end{array}$ & 40 & 2005 & \\
\hline 08 & Zarifet & Zarifet & Zarifet 1 & $\begin{array}{c}34^{\circ} 50^{\prime} 15.1^{\prime \prime} \mathrm{N} \\
1^{\circ} 22^{\prime} 49.0^{\prime \prime} \mathrm{O}\end{array}$ & 40 & 2005 & \\
\hline 09 & Zarifet & Zarifet & Zarifet 1 & $\begin{array}{c}34^{\circ} 50^{\prime} 07.6^{\prime \prime} \mathrm{N} \\
1^{\circ} 23^{\prime} 08.9^{\prime \prime} \mathrm{O}\end{array}$ & 50 & 2005 & \\
\hline
\end{tabular}

The density of reforestation, in the Hafir state forest, varies between 333 and 625 plants per hectare. In Zarifet, this density is between 625 and 800 seedlings/ha [74]. Regardless of the plot taken into account, we observe that planting densities are rather low compared to different reforestation areas around the Mediterranean region [75]. By way of comparison, in the Mamora region of Morocco, planting density varies between 900 and 2500 plants/ha, with an average of 1500 plants / ha for cork oak [75]. This can be explained by the insufficient means and the unavailability of oak seedlings (Figure 10).

However, the success of Aleppo pine and gable pine is encouraging, although it is accepted that the potential forest in the Tlemcen Mountains should be broadleaved deciduous forests [40]. In places where cork oak plants are protected by low woody vegetation (such as holm oak), foresters have recorded significant success rates, with the regeneration of cork oak taking most of the time in multi-stratum systems where the clearing of woody vegetation has been finely dosed $[40,76,77]$. 


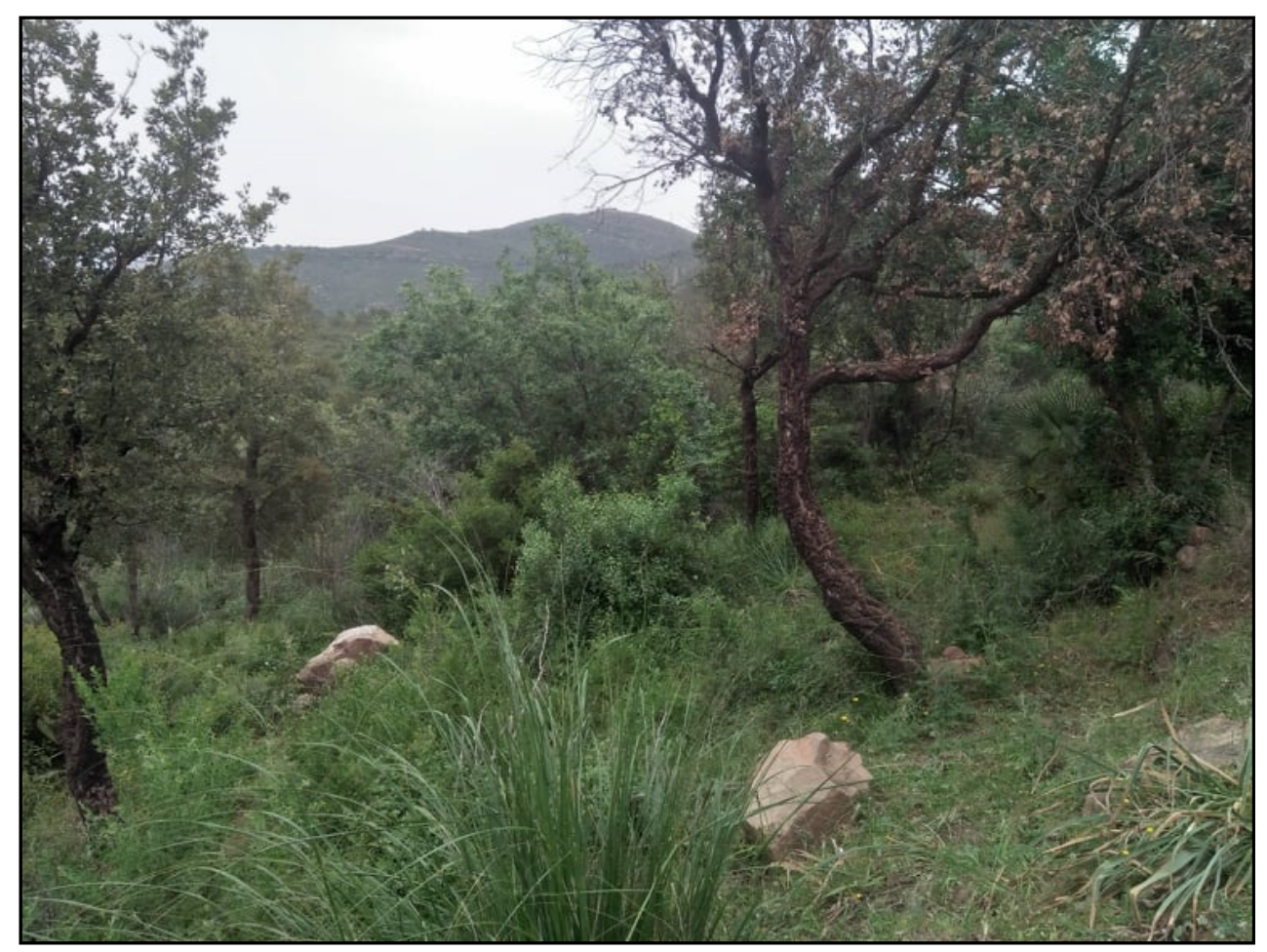

Figure 10. Regeneration of cork oak forest (Quecus suber) after awildfirein Zarifet forest. (Photograph by authors, taken on 25 March 2017).

\subsection{Progress of the Agricultural Area}

The National Park covers an area of more than 8337 ha and has a population of around 9728 inhabitants, resulting in a density of 1.18 inhabitants/ha. In the territory of the seven municipalities included in the park, agricultural activity is predominant. Given the configuration of the relief, it is mountain agriculture, reduced to a system of extensive crops (fruit and cereal plantations) complemented by beekeeping, sheep, cattle, and small traditional poultry. There are some secondary but original practices such as the harvesting of large oaks (consumption), the exploitation of cork, the carbonization (practiced after fires or in traditional and often illicit charcoal kilns), the gathering of medicinal and aromatic plants, the harvesting of honey, handicrafts (tapestry, spinning, and wool work) and very limited hunting and fishing which is practiced at the Meffrouch dam. Finally, the park is also home to sedentary game species including rabbits, hare, quails, wild boars, and partridges. In total, the agricultural sector supports 430 farmers on $1740 \mathrm{ha}$, and 750 breeders [78]. It also provides interesting provisions to promote agrotourism. The main cherry festival in June in Mansourah remains the most considerable agricultural manifestation.

The reduction of wooded areas at the interface between forest and agricultural land is more likely to occur in low scrubland and open woodland than in dense mature forests, given the ease with which the surrounding areas can be cleared. Tree orchards such as cherry and olive groves represent an interesting transition between forest and agricultural areas. The cherry trees also give the region its reputation and add value to the economy of the piedmonts. The public authorities have greatly encouraged the planting of fruit trees. In recent years, numerous programs such as the rural employment program (REP) (1996-2006) and the proximity project for integrated rural development (PPIRD) (2007-2015) or the national agricultural development plan (2015-2025) have led to the extensive planting of fruit trees in the western part of the country. The region of Tlemcen, considered as a pilot region of this program, has benefited from 24,727 ha $(54 \%)$ of fruit tree plantations. A part from the other programs, the REP alone made it possible, between 1989 and 2005, to increase the area of fruit species in the region by $44 \%$, considering 1997 as the launch period. In the region 
of Tlemcen, this area more than doubled (57\%), thanks to REP1.The multiplication by more than 3 of the surfaces dedicated to arboriculture and market gardening during the period 2005-2017 testifies to this dynamic, apparently amplified by private initiatives. A major part of this increase corresponds in similar parts, to a conversion of fallow lands and the plantation of orchards in degraded surfaces, and thus to a real valorization in land use.

However, the economic motivation of the local population practicing this activity (providing a substantial economic income) should encourage park managers to ensure that forest areas are respected to avoid a decline in forest species and the shrinking of forested areas. The planting of fruit trees is commendable in the context of the integrated management of the park (550 people are engaged in mountain arboriculture) but cannot sustainably protect the mountainous areas. A gradual transition through hardy strip orchards with olive, cherry, and almond trees would be a model that seems appropriate to halt this decline.

Grazing in the interfaces may not be dangerous if controlled, but the laxity of forest services' vigilance encourages the local population and residents to transgress the forest area and, consequently, creates difficulties in regenerating the forest cover (soil compaction and grazing of young plants). Given the complexity of livestock flows in search of plant resources, almost the entire surface of the study area is used as grazing land by the local population (6550.5 ha). According to [79-81], the sharp decline of the forested areas and their pastoral value is due to the increase in the number of livestock, which leads to a pastoral overload leading to a reduction in rangelands. Nevertheless, our analysis leads to more subtle conclusions. The persistent degradation of forest areas is due to a wide range of livestock compared to the pastoral capacities of the plant formations, although the situation varies from one commune to another, characterized by low pressure in the municipalities of Tlemcen-Mansourah and Ain Fezza, with an index of pastoral load fluctuating between 0.74 and $0.98 \mathrm{U} . \mathrm{O} / \mathrm{ha}$. This load is average in the communes of Terny and Ain Ghoraba with 1.71 to $1.81 \mathrm{U} . \mathrm{O} / \mathrm{ha}$. The commune of Beni Mester has the highest pastoral load with 6 U.O./ha [60]. The significant part of spontaneous recovery limited to the scrubland stage of plant succession, shown by our analysis, could be explained partly by this remaining anthropogenic pressure, particularly in Beni Mester territory. Further verifications would be necessary to check if the dynamics of the vegetation vary according to the pastoral load in the different municipalities, as suggested by visual and field observations (Figures 11 and 12).

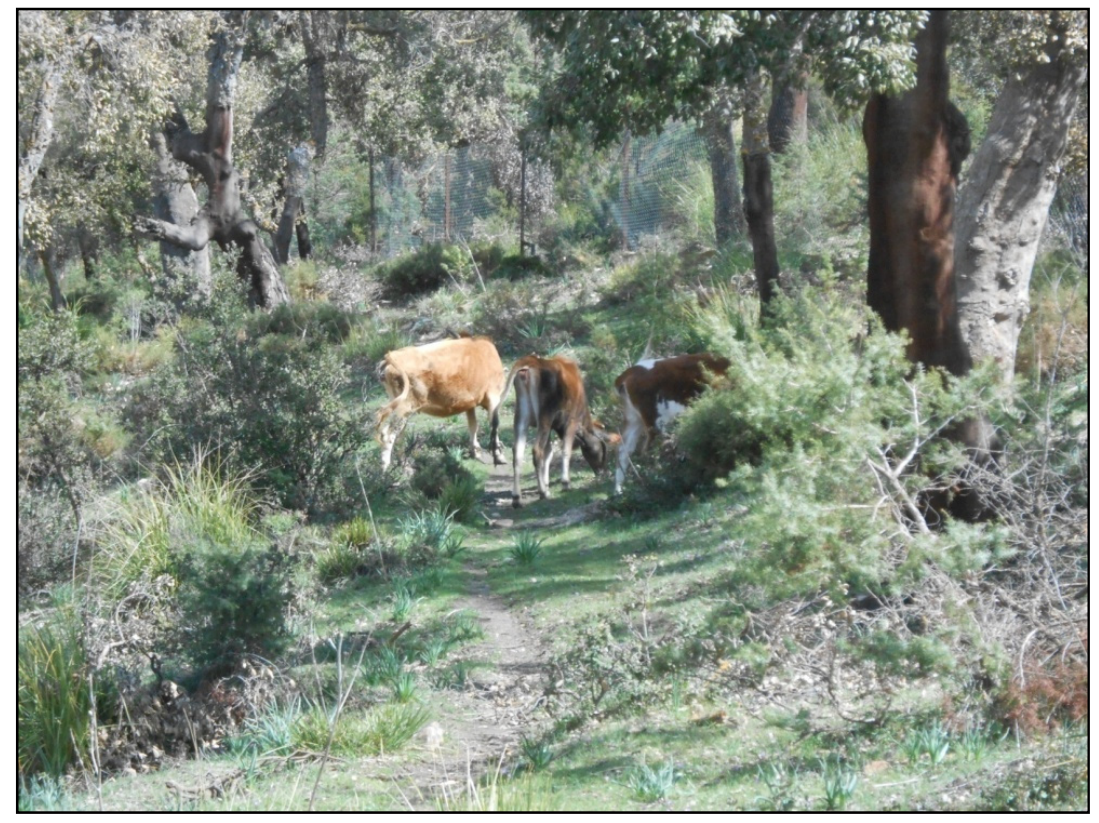

Figure 11. Low-pressure grazing by bovines in Zarifet forest (Mansourah) (Photograph by authors, taken on 25 March 2017). 


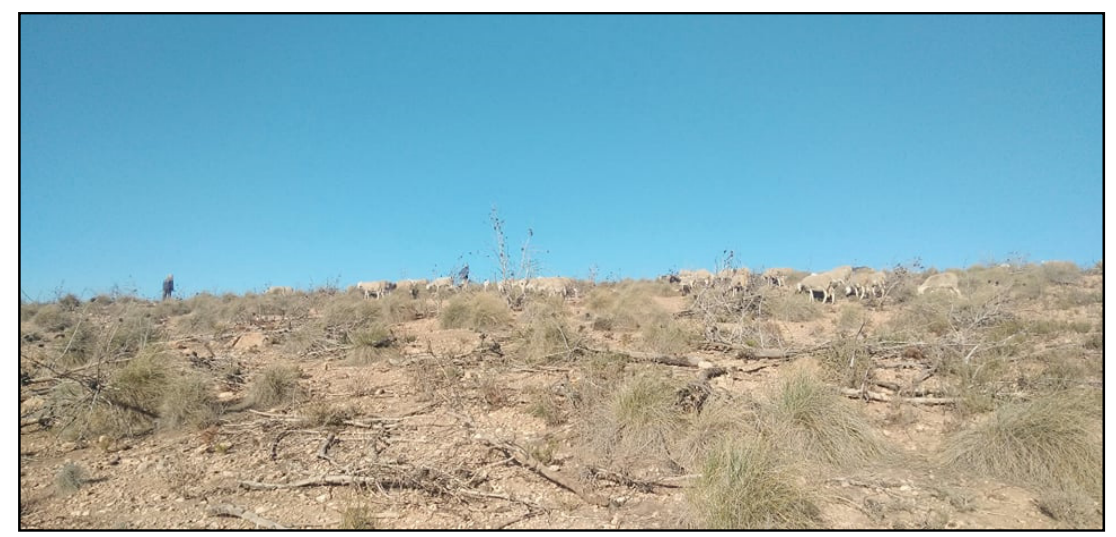

Figure 12. High-pressure sheep grazing in the region of Hafir (Beni Mester) (Photograph by authors, taken on 30 April 2017).

\subsection{Progression of the Built Areas}

The floristic and structural variety of the park, combined with the proximity of the urban agglomerations of the seven capitals of the municipalities integrated into the park, increases the risks of landscape degradation at the forest-habitat interface, particularly the advance of urbanization which restructures the landscape and tends to fragment it, as observed in the proximity of other protected parks [14].

The slackening of forest services and political circumstances has contributed to the establishment of several family dwellings forming real villages within the forest areas.

It should also be remembered that public authorities, through Executive Decree No. 10-87 of 10 March 2010, have greatly encouraged rural housing during the years 2000 to 2017 to settle the local population following a major rural exodus in the 1990s, which has favored the creation of a forest/housing interface.

Indeed, the PPIRD project launched in 2007, by the Ministry of Agriculture and Rural Development, has encouraged rural people to build on their land, which has been very popular with the rural population.

The progression of urbanization can also be explained by the establishment of the Lalla Setti plateau as a tourist zone and the national park house on a surface area of 80 ha. The plateau of Lalla Setti (highly urbanized), which is situated in a wide interface with the state forest of Tlemcen, represents an important place for the reception of hundreds of city dwellers and tourists (Figure 13).

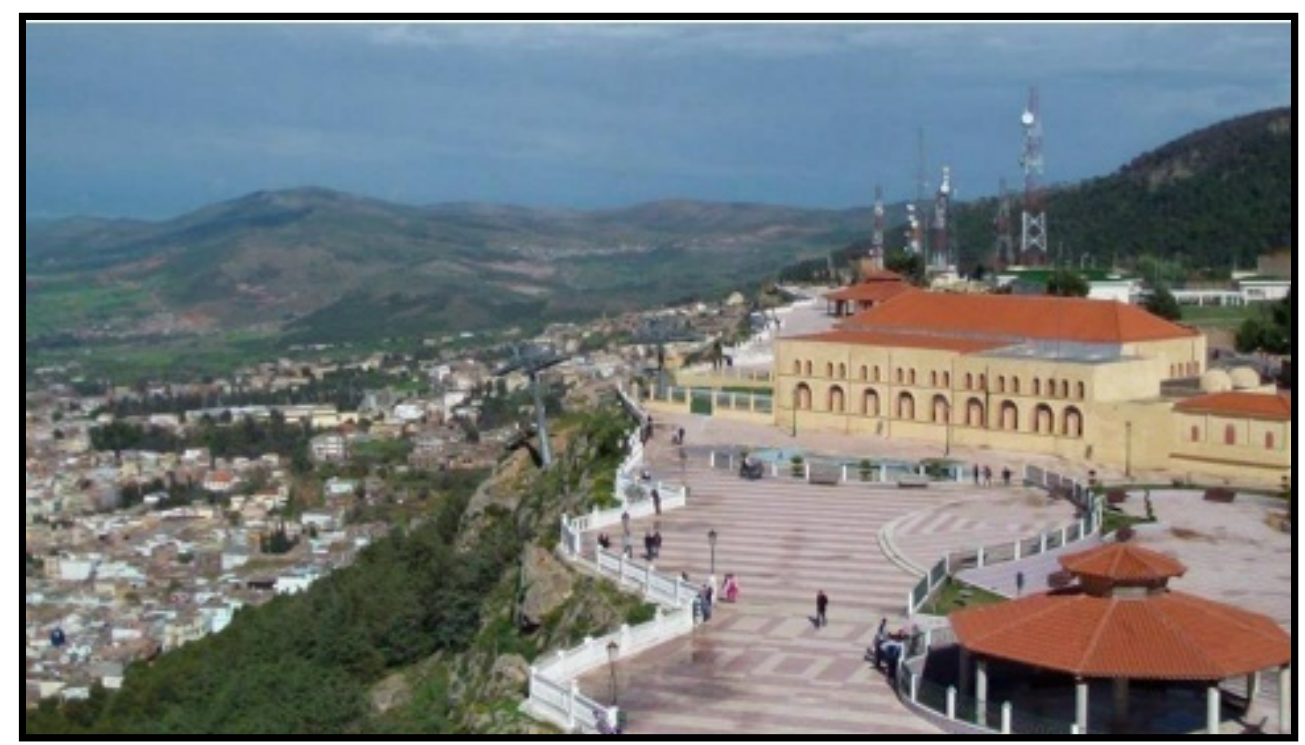

Figure 13. The leisure park of the Plateau of Lalla Setti (Tlemcen) [82]. 


\subsection{Synthesis}

Contrary to a widespread idea in the literature dealing with vegetation degradation in Algeria [83-87], our study showed that the situation was more complex and we note a resilience capacity of the natural vegetation (in particular the reconstitution of the scrubland after the fire). This has been highlighted by several authors $[4,10,11,88]$ despite the significant disturbances experienced during a period characterized by an accumulation of political and economic difficulties. In addition, the very significant efforts made by foresters have made it possible to reconstitute part of the forest stands previously destroyed following the major fires. Similarly, the development programs undertaken in the region have enabled the local population to convert to more remunerative agricultural systems (olive growing), thus limiting overgrazing, often considered to be the main factor in the degradation of the vegetation cover in the Mediterranean region [60,89-91]. The development of local tourism could perhaps constitute an additional source of income. Overall, our results are closer to those reported by the FAO and the Blue Plan (2018), which noted small changes in a forest area during the period 1990 and 2015 in the Southern Mediterranean, including Algeria, whereas it increased in the North, contrary to other authors associating the Southern Mediterranean with a trend towards regression of forests [4].

\section{Conclusions}

The use of remote sensing data made it possible to map LULC from 1987 to 2017 in TNP. The maps produced based on the Landsat image extracts used and the analysis of the results haven abled the eCognition program to be understood. More precisely and from a semantic point of view, the product of segmentation and classification for LULC is more meaningful and more in line with the reality on the ground. This technique has greatly helped us to highlight the modifications with conversions between the different LULC classes, particularly the regression of forested areas following repeated fires since 1987 and the resulting appearance of rocky outcrops.

Tlemcen forest shows a non-linear evolution during our study period, contrary to many authors indicating a trend towards the degradation of Mediterranean forests. The interest of a long study period is to highlight these breaks in trends.

Despite these regressions and disturbances of the forest area, the current woodland area represents an important forest heritage that should be protected and strengthened so that the park can perform its landscape protection functions. It bears witness to the success of the reforestation policy implemented by the Park's managers and the natural recovery of burnt and degraded land. In this context, optimizing reforestation success rates is a priority for TNP managers and forestry services.

However, in parallel with this positive evolution through reforestation and natural reclamation, we observe the emergence of landscape problems at the boundaries between the different interfaces-woodland-built area and woodland-agricultural area-linked to a trend towards urbanization and agricultural intensification encouraged by rural development programs and the increase in tourist numbers. Without denying their economic interest for the local population and indirect benefits by decreasing the intensity of anthropogenic pressure in woodlands and scrublands, it would be judicious to envisage respectively buffer and transition areas with trees (minimum of $200 \mathrm{ha}$ ) to mitigate these effects of abrupt edges unfavorable to forest areas. Forestry and environmental law considering the landscape aspect in general and the landscape risks at the forest-built and forest-agricultural land interfaces would be necessary. This change map is proving to be a good decision-making tool for field managers to better understand the evolution of land use in their region and to rank priorities for intervention.

Author Contributions: Conceptualization, Z.S. and M.C.; methodology, M.C. and Z.S.; software, A.B.; validation, A.B.; formal analysis, A.B., M.C. and Z.S.; investigation, A.B.; resources, A.B.; data curation, A.B.; writing-original draft preparation, A.B., M.C. and Z.S.; writing-review and editing, A.B., Z.S., M.C. and M.A.; visualization, A.B., M.C. and Z.S.; supervision, Z.S. and M.C.; 
project administration, Z.S. and A.B. All authors have read and agreed to the published version of the manuscript.

Funding: This research received no external funding.

Institutional Review Board Statement: Not applicable.

Informed Consent Statement: Not applicable.

Data Availability Statement: All data generated or analyzed during this study are included in this published article.

Acknowledgments: The authors express their gratitude to the Tlemcen National Park for access to their data. A big thanks to the Médiations laboratory (Sorbonne University) and the whole team of the GeoTeCa (University of Paris) for their welcome and scientific support. Thanks to Sophie Adelaide Magnier (Grenoble Alpes University) for the English revision.

Conflicts of Interest: The authors declare no conflict of interest.

\section{References}

1. Scarascia-Mugnozza, G.; Oswald, H.; Piussi, P.; Radoglou, K. Forests of the Mediterranean region: Gaps in knowledge and research needs. For. Ecol. Manag. 2000, 132, 97-109. [CrossRef]

2. Conard, S.G.; Hartzell, T.; Hilbruner, M.W.; Zimmermam, G.T. Changing fuel management strategies-The challenge of meeting new information and analysis needs. Int. J. Wildland Fire 2001, 10, 267-275. [CrossRef]

3. Balzan, M.V.; Hassoun, A.E.R.; Aroua, N.; Baldy, V.; Bou Dagher, M.; Branquinho, C.; Dutay, J.-C.; El Bour, M.; Médail, F.; Mojtahid, M.; et al. Ecosystems. In Climate and Environmental Change in the Mediterranean Basin-Current Situation and Risks for the Future; First Mediterranean Assessment Report; Cramer, W., Guiot, J., Marini, K., Eds.; Union for the Mediterranean, Plan Bleu, UNEP/MAP: Marseille, France, 2020; pp. 323-468.

4. Gauquelin, T.; Michon, G.; Joffre, R.; Duponnois, R.; Génin, D.; Fady, B.; Dagher-Kharrat, M.B.; Derridj, A.; Slimani, S.; Badri, W. Mediterranean forests, land use and climate change: A social-ecological perspective. Reg. Environ. Chang. 2018, $18,623-636$. [CrossRef]

5. Lionello, P.; Abrantes, F.; Gacic, M.; Planton, S.; Trigo, R.; Ulbrich, U. The climate of the Mediterranean region: Research progress and climate change impacts. Reg. Environ. Chang. 2014, 14, 1679-1684. [CrossRef]

6. Loizidou, M.; Giannakopoulos, C.; Bindi, M.; Moustakas, K. Climate change impacts and adaptation options in the Mediterranean basin. Reg. Environ. Chang. 2016, 16, 1859-1861. [CrossRef]

7. Pausas, J.G. Changes in fire and climate in the eastern Iberian Peninsula (Mediterranean basin). Clim. Chang. 2004, 63, 337-350. [CrossRef]

8. Tramblay, Y.; Llasat, M.C.; Randin, C.; Coppola, E. Climate change impacts on water resources in the Mediterranean. Reg. Environ. Chang. 2020, 20, 3. [CrossRef]

9. Barbero, M. Témoignage: Pierre Quézel et les montagnes méditerranéennes/Testimony: Pierre Quézel and Mediterranean mountains. Ecol. Mediter. 2018, 44, 23-29.

10. Keeley, J.E.; Bond, W.J.; Bradstock, R.A.; Pausas, J.G.; Rundel, P.W. Fire in Mediterranean Ecosystems: Ecology, Evolution and Management; Cambridge University Press: Cambridge, UK, 2011.

11. Mouillot, F.; Rambal, S.; Limousin, J.; Longepierre, D.; Kheder Chiraz, B.; Ouelhazi, B. Mediterranean ecosystems facing global change: Resilient or close to tipping point? In The Mediterranean Region under Climate Change: A Scientific Update; Thiébault, S., Moatti, J.-P., Eds.; IRD Editions: Marseille, France, 2016; pp. 349-361.

12. Garcia-Ruiz, J.M.; Lasanta, T.; Ruiz-Flano, P.; Ortigosa, L.; White, S.; González, C.; Martí, C. Land-use changes and sustainable development in mountain areas: A case study in the Spanish Pyrenees. Landsc. Ecol. 1996, 11, 267-277. [CrossRef]

13. Lasanta-Martínez, T.; Vicente-Serrano, S.M.; Cuadrat-Prats, J.M. Mountain Mediterranean landscape evolution caused by the abandonment of traditional primary activities: A study of the Spanish Central Pyrenees. Appl. Geogr. 2005, 25, 47-65. [CrossRef]

14. Cohen, M.; Decaudin, B.; Llausas, A. Concilier les Objectifs de Protection de la Nature et de Lutte contre l'Incendie. In Proceedings of the 25th International Cartographic Conference, Paris, France, 3-8 July 2011; Ruas, A., Ed.; Paper CO-107. International Cartographic Association: Berna, Switzerland, 2011; p. 8.

15. FAO. Negotiating a Sustainable Future for Land: Structural and Institutional Guidelines for Land Resources Management in the 21st Century; FAO/UNED: Rome, Italy, 1997.

16. Papanastasis, V.P. Land use changes. In Mediterranean Mountain Environment; UNEP/MAP: Marseille, France, 2012; pp. 159-184.

17. Sitayeb, T.; Benabdeli, K. Contribution à l'étude de la dynamique de l'occupation des sols de la plaine de la Macta (Algérie) à l'aide de la télédétection et des systèmes d'information géographique. Comptes Rendus Biol. 2008, 331, 466-474. [CrossRef]

18. McNeill, J.R. The Mountains of the Mediterranean World: An Environmental History; Cambridge University Press: Cambridge, UK, 1992. 
19. Labani, M.M.; Rezaee, R. The importance of geochemical parameters and shale composition on rock mechanical properties of gas shale reservoirs: A case study from the Kockatea Shale and Carynginia Formation from the Perth Basin, Western Australia. Rock Mech. Rock Eng. 2015, 48, 1249-1257. [CrossRef]

20. Alcaraz, C. Etude Géobotanique du Pin d'Alep dans le Tell Oranais. Ph.D. Thesis, Université de Montpellier, Montpellier, France, 1969; p. 183.

21. Alcaraz, C. La Végétation de l'Ouest Algérien. Ph.D. Thesis, Université de Perpignan, Perpignan, France, $1982 ;$ p. 415.

22. Boudy, P. Economie Forestière Nord-Africaine-Tome 1: Milieu Physique et Milieu Humain; Larose, E., Ed.; CIRAD: Paris, France, 1948.

23. FOSA. L'Étude Prospective du Secteur Forestier en Afrique, Algérie; FAO: Rome, Italy, 2000; p. 60.

24. Kadik, B. Aperçu sur sols et la végétation des pineraies d'Eghti (Sidi-Bel-Abbes). Annal. Rech. For. Algérie 1986, 1, 7-22.

25. Missoumi, A.; Mederbal, K.; Abedelli, K. Apport des SIG dans la prévention et la lutte contre les incendies de forêt. Exemple de la forêt domaniale de Kounteidat, Algérie. For. Méditer. 2002, 23, 11-22.

26. Velez, R. Protection Contre les Incendies de Forêt: Principes et Méthodes d'Action; CIHEAM: Série B: Etudes et Recherches, No 26; Options Méditerranéennes; IFFN: Zaragoza, Spain, 1999.

27. Zahira, S.; Hadj, B. L'Algérie: Une région méditerranéenne très sensible aux incendies de foret. Territorium 2017, 1, 177-186. [CrossRef]

28. Zeraia, L. Essai d'Interprétation Comparative des Données Écologiques, Phénologiques et de Production Subéro-Ligneuse dans les Forêts de Chêne-Liège de Provence Cristalline (France Méridionale) et d'Algérie. Ph.D. Thesis, University of Aix-Marseille, Marseille, France, 1981; p. 367.

29. Barbero, M.; Bonin, G.; Loisel, R.; Quézel, P. Changes and disturbances of forest ecosystems caused by human activities in the western part of the Mediterranean basin. Vegetatio 1990, 87, 151-173. [CrossRef]

30. Boer, M.M.; Puigdefábregas, J. Predicting potential vegetation index values as a reference for the assessment and monitoring of dry land condition. Int. J. Remote Sens. 2003, 24, 1135-1141. [CrossRef]

31. Boer, M.M.; Puigdefábregas, J. Assessment of dry land condition using spatial anomalies of vegetation index values. Int. J. Remote Sens. 2005, 26, 4045-4065. [CrossRef]

32. Holm, A.M.; Cridland, S.W.; Roderick, M.L. The use of time-integrated NOAA NDVI data and rainfall to assess landscape degradation in the arid scrubland of Western Australia. Remote Sens. Environ. 2003, 85, 145-158. [CrossRef]

33. Le Houérou, H.N. Climate change, drought and desertification. J. Arid Environ. 1996, 34, 133-185. [CrossRef]

34. Ludwig, J.A.; Tongway, D.J. Viewing rangelands as landscape systems. In Rangeland Desertification; Springer: Berlin/Heidelberg, Germany, 2000; pp. 39-52.

35. Paruelo, J.M.; Sala, O.E.; Beltrán, A.B. Long-term dynamics of water and carbon in semi-arid ecosystems: A gradient analysis in the Patagonian steppe. Plant Ecol. 2000, 150, 133-143. [CrossRef]

36. Ramade, F. Dictionnaire Encyclopédique de l'Écologie et des Sciences de l'Environnement; Ediscience International: Marseille, France, 1993.

37. Le Coz, J. Espaces Méditerranéens et Dynamiques Agraires. État Territorial et Communautés Rurales; Options Méditerranéennes: Série B. Etudes et Recherches, n² 2; CIHEAM: Montpellier, France, 1990; p. 393.

38. Bouiadjra, S.E.B.; Zerey, W.E.; Benabdeli, K. Étude diachronique des changements du couvert végétal dans un écosystème montagneux par télédétection spatiale: Cas des monts du Tessala (Algérie occidentale). Physio-Géo. Géogr. Phys. Environ. 2011, 5, 211-225. [CrossRef]

39. Gaouar, A. Hypothèses et réflexions sur la dégradation des écosystèmes forestiers dans la région de Tlemcen (Algérie). For. Méditer. 1980, 2, 131-146.

40. Meslinée Bestaoui, K. Contribution à une Étude Écologique et Dynamique de la Végétation des Monts de Tlemcen par une Approche Cartographique; Faculté des Science, Université Abou Bekr Belkaïd: Tlemcen, Algiers, 2009.

41. Zenagui, N. Synthèse Phylogénétique des Communautés Végétales dans les Matorrals des Monts de Tlemcen. Ph.D. Thesis, Université de Tlemcen, Algiers, Algeria, 2017; 245p.

42. Martín-Ortega, P.; Segur, M. FAO and Plan Bleu, 2018. State of Mediterranean Forests 2018; Food and Agriculture Organization of the United Nations: Rome and Plan Bleu, Marseille, 2018. Available online: http://planbleu.org/en/publications/statemediterranean-forests-2018 (accessed on 15 September 2019).

43. Lu, D.; Mausel, P.; Brondizio, E.; Moran, E. Change detection techniques. Int. J. Remote Sens. 2004, 25, 2365-2401. [CrossRef]

44. Mas, J. Une revue des méthodes et des techniques de télédétection du changement. Can. J. Remote Sens. 2000, 26, 349-362. [CrossRef]

45. Abdelguerfi, A. Mises en CEuvre des Mesures Générales pour la Conservation In Situ et Ex Situ et l'Utilisation Durable de la Biodiversité en Algérie Bilans des Expertises (Tome 2); Plan d'Action et Stratégie Nationale sur la Biodiversité Projet ALG/97/G31, Rapport de synthèse; Ministère de l'Aménagement du Territoire et de l'Environnement: Alger, Algiers, 2003; p. 109.

46. Letreuch-Belarouci, A.; Medjahdi, B.; Letreuch-Belarouci, N.; Benabdeli, K. Diversité floristique des subéraies du parc national de Tlemcen (Algérie). Acta Bot. Malacit. 2009, 34, 77-89. [CrossRef]

47. Organisation de Cooperation et de Developpement Economiques (OCDE). Stratégies Nationales de Développement Durable: Bonnes Pratiques dans les Pays de l'OCDE; Edition de l'OCDE; OCDE: Paris, France, 2006; 38p.

48. Loukkas, A. Atlas des Parcs Nationaux Algériens; Ministère Agriculture et Développement Rural, Direction des Forêts: Alger, Algiers, 2006; p. 96. 
49. Tlemcen, P. Plan de Gestion (2006-2010) Rapport de Ministère de l'Agriculture et du Développement Rural, PNT; Ministère Agriculture et Développement Rural: Alger, Algiers, 2009.

50. Benabadji, N.; Benmansour, D.; Bouazza, M. La flore des monts d'Ain Fezza dans l'ouest algérien, biodiversité et dynamique. Sci. Technol. C Biotechnol. 2007, 26, 47-59.

51. Siba, A. Contribution à l'Étude du Bilan Floristique dans les Matorrals Sud et Nord de Tlemcen. Ph.D. Thesis, University of Aboubekr Belkaïd, Tlemcen, Algiers, 2016; p. 257.

52. Andrieu, J. Dynamique des Paysages dans les Régions Septentrionales des Rivières-du-Sud (Sénégal, Gambie, Guinée-Bissau). Ph.D. Thesis, University Paris Diderot, Paris, France, 2008; pp. 7-532.

53. Ducrot, D. Méthodes d'Analyse et d'Interprétation d'Images de Télédétection Multi-Sources. Extraction de Caractéristiques du Paysage. Habilitation à Diriger des Recherches. Ph.D. Thesis, INP, Toulouse, France, 2005.

54. Bolon, P.; Chassery, J.-M.; Cocquerez, J.-P.; Demigny, D.; Graffigne, C.; Montanvert, A.; Philipp, S.; Zéboudj, R.; Zerubia, J.; Maître, H. Analyse d'Images: Filtrage et Segmentation; Masson: Paris, France, 1995.

55. Derrar, I. Contribution à la Correction Radiométrique des Images d'ALSAT-1: Application de la Méthode Dite Calibration Indirecte; Mémoire de magister; Univ. Sciences et Technologie d'Oran Mohamed Boudiaf: Bir El Djir, Algiers, $2014 ;$ p. 109.

56. Corbane, C.; Baghdadi, N.; Chevrel, S. Application d'une méthode de classification orientée objet pour la cartographie de l'occupation du sol: Résultats sur ASTER et Landsat ETM. Rev. Fr. Photogramm. Télédétect 2004, 175, 13-26.

57. Ballais, J.-L.; Barussaud, E.; Cohen, M.; Raymond, R.; Thommeret, N. Dynamiques des Paysages, Érosion et Développement Durable dans les Montagnes Méditerranéennes. Programme de Recherche, Paysages et Développement Durable; Rapport final d'activité; Cohen, M., Ed.; LADYSS: Paris, France, 2008; p. 74.

58. Achbun, A.; Mansour, M.; Layelmam, M.; Smiej, M.F. Etude comparative de la classification orientée objet d'une image SPOT 5 pour la cartographie de l'occupation du sol via eCognition ${ }^{\circledR}$ 9. Geo Obs. 2011, 9, 13.

59. Delahaye, A. Classification Multiéchelle d'Images à très Haute Résolution Spatiale Basée sur une Nouvelle Approche Texturale. Ph.D. Thesis, Faculté des Lettres et Sciences Humaines, Université de Sherbrooke, Sherbrooke, QC, Canada, 2016.

60. Benaissa, H.; Benabdeli, K. Evaluation de l'impact du parcours sur la végétation du Parc national de Tlemcen (Algérie nordoccidentale). Geo-Eco-Trop J. 2019, 43, 129-136.

61. Project, F.R.A. Forest Resources Assessment 1990: Survey of Tropical Forest Cover and Study of Change Processes; Food \& Agriculture Organization: Rome, Italy, 1996.

62. Bernier, B. Introduction à la Macroéconomie; La Découverte: Paris, France, 1992; p. 217.

63. Mama, V.J.; Oloukoi, J. Évaluation de la précision des traitements analogiques des images satellitaires dans l'étude de la dynamique de l'occupation du sol. Télédétection 2003, 3, 429-441.

64. Oloukoi, J.; Mama, V.J.; Agbo, F.B. Modélisation de la dynamique de l'occupation des terres dans le département des collines au Bénin. Télédétection 2006, 6, 305-323.

65. Soro, G.; Anouman, D.; BI, T.G.; Srohorou, B.; Savane, I. Caractérisation des séquences de sècheresse météorologique à diverses échelles de temps en climat de type soudanais: Cas de l'extrême nord-ouest de la Cote d'Ivoire. Larhyss J. 2014, 18, 107-124.

66. Bamba, I.; Mama, A.; Neuba, D.; Koffi, K.J.; Traore, D.; Visser, M.; Sinsin, B.; Lejoly, J.; Bogaert, J. Influence des actions anthropiques sur la dynamique spatio-temporelle de $1 \backslash$ 'occupation du sol dans la province du Bas-Congo (RD Congo). Sci. Nat. 2008, 5, 49-60. [CrossRef]

67. Schlaepfer, R. Analyse de la dynamique du paysage. Fiche Enseign. 2002, 4, 11.

68. Bouhraoua, R. Situation Sanitaire de Quelques Forêts de chêne-Liège de l'Ouest Algérien: Étude Particulière des Problèmes Posés par les Insectes. Ph.D. Thesis, University of Tlemcen, Tlemcen, Algiers, 2003.

69. AEFCO. Description des Peuplements de la Forêt Domaniale de Zarifet; AEFCO: Peyton, CO, USA, 1912.

70. Boudy, P. Economie Forestière Nord-Africaine. Tome 2: Monographies et Traitements des Essences Forestières; Editions Larousse: Paris, France, 1950; p. 878.

71. Weise, D.R.; Biging, G.S. A qualitative comparison of fire spread models incorporating wind and slope effects. For. Sci. 1997, 43, 170-180.

72. Lasanta, T.; Arnáez, J.; Pascual, N.; Ruiz-Flaño, P.; Errea, M.; Lana-Renault, N. Space-time process and drivers of land abandonment in Europe. Catena 2017, 149, 810-823. [CrossRef]

73. Office National de la Météorologie (ONM) et de la Direction Générale des Forêts (DGF). Réduction D'échelle et Modélisation Climatique avec Une Application à la Gestion des Forêts en Algérie; ClimaSouth-Technical Paper 4; Projet national: Algiers, Algeria, 2018; p. 57.

74. Berriah, A. Les Reboisements de Chêne Liège dans l'Ouest Algérien: Bilan et Perspectives d'Amélioration; Mémoire de Magister; University Abou Bakr Belkaïd: Tlemcen, Algiers, 2015; p. 158.

75. Messaoudene, M.; Rabhil, K.; Megdoud, A.; Sarmoun, M.; Dahmani-Megrerouche, M. Etat des lieux et perspectives des cédraies algériennes. For. Méditer. 2013, 34, 341-346.

76. Belghazi, B.; Ezzahiri, M.; Amhajar, M.; Benziane, M. Régénération artificielle du chêne-liège dans la forêt de la Mâamora (Maroc). For. Méditer. 2001, 22, 253-261.

77. Naggar, M. Problématique d'aménagement sylvopastoral au Maroc. Cas du projet d'aménagement sylvopastoral de la forêt de la Mâamora. In Systèmes Sylvopastoraux. Pour un Environnement, une Agriculture et une Économie Durables; (Cahiers Options Méditerranéennes; n. 12; CIHEAM: Zaragoza, Spain, 1995; pp. 165-168. 
78. Boumaza, H.B. Vers une Gestion Durable des Ressources en Eau du Parc National de Tlemcen. Ph.D. Thesis, University Aboubekr Belkaïd, Tlemcen, Algiers, 2012; p. 150.

79. Aidoud, A. Contribution à l'Étude des Écosystèmes Pâturés des Haute Plaines Algéro-Oranaises. Fonctionnement, Évaluation, et Évolution des Ressources Végétales. Ph.D. Thesis, USTH, Tlemcen, Alger, 1989; p. 180.

80. Djellouli, Y.; Nedjraoui, D. Evolution des parcours méditerranéens. In Pastoralisme: Troupeaux, Espaces et Sociétés; Daget, P. Godron, M., Eds.; Hatier et AUPELF-UREF: Paris, France, 1995; pp. 440-454.

81. Benabdelli, K. Aspect Physionomico-Structural et Dynamique des Écosystèmes Forestiers Face à la Pression Anthropozoogène dans les Monts de Tlemcen et des Monts des Dhayas (Algérie Septentrionale Occidentale). Ph.D. Thesis, University Sidi-Bel-Abbès, Sidi Bel Abbès, Algiers, 1996; p. 215.

82. Sekkoum, S.; Maachou, H.M. Le parc national de Tlemcen (Algérie): Un potentiel touristique sous-exploité. Études Caribéennes 2016, 39-40. [CrossRef]

83. Arfa, A.M.T.; Benderradji, M.E.H.; Saint-Gérand, T.; Alatou, D. Cartographie du risque feu de forêt dans le Nord-est algérien: Cas de la wilaya d'El Tarf. Cybergeo Eur. J. Geogr. 2019. [CrossRef]

84. Benabadji, N.; Bouazza, M.; Mahboubi, A. L'impact de l'homme sur la foret dans la région de Tlemcen (Oranie-Algérie). Rev. For. Méditer. 2001, 22, 269-274.

85. Cherifi, K.; Mehdadi, Z.; Latreche, A.; Bouiadjara, S.E.B. Impact de l'action anthropozoogène sur l'écosystème forestier du mont de Tessala (Algérie occidentale). Sci. Chang. Planét. Sécher. 2011, 22, 197-206.

86. Djeddaoui, F.; Chadli, M.; Gloaguen, R. Desertification susceptibility mapping using logistic regression analysis in the Djelfa area, Algeria. Remote Sens. 2017, 9, 1031. [CrossRef]

87. Kherchouche, D.; Kalla, M.; Gutierrez, E.; Briki, A.; Hamchi, A. La sécheresse et le dépérissement du cèdre de l'Atlas (Cedrus atlantica Manetti) dans le massif du Belezma (Algérie). Sci. Chang. Planet. Sécher. 2013, 24, 129-137.

88. Quézel, P.; Médail, F. Ecologie et Biogéographie des Forêts du Bassin Méditerranéen; Elsevier: Paris, France, 2003 ; p. 571.

89. Le Houérou, H.N. L'impact de l'homme et de ses animaux sur la forêt méditerranéenne. 2ème partie. For. Méditer. 1980, 2, 155-174.

90. Said, L.; Assmaa, A.; Najib, G.; Gmira, N. Contribution à l'évaluation de la pression pastorale dans la forêt de la Maamora. Parcours forestiers et surpâturage. Nat. Technol. 2014, 6, 39.

91. Saidi, B.; Latrèche, A.; Hakemi, Z.; Mehdadi, Z.; Bouker, A. Dynamique post-perturbation (post-incendie ou post-surpâturage) des communautés végétales des monts de Tessala, Algérie occidentale. Ecol. Mediter. 2016, 42, 41-49. [CrossRef] 